\title{
AGR-3/4 Irradiation Test Predictions using PARFUME
}

William F. Skerjanc

March 2016

The INL is a

U.S. Department of Energy

National Laboratory

operated by

Battelle Energy Alliance

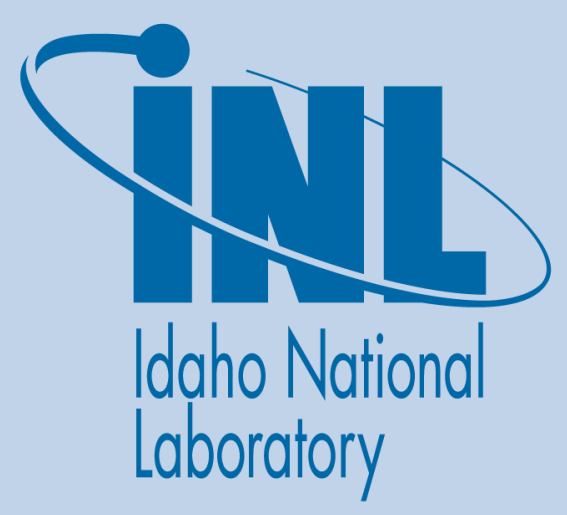




\section{DISCLAIMER}

This information was prepared as an account of work sponsored by an agency of the U.S. Government. Neither the U.S. Government nor any agency thereof, nor any of their employees, makes any warranty, expressed or implied, or assumes any legal liability or responsibility for the accuracy, completeness, or usefulness, of any information, apparatus, product, or process disclosed, or represents that its use would not infringe privately owned rights. References herein to any specific commercial product, process, or service by trade name, trade mark, manufacturer, or otherwise, does not necessarily constitute or imply its endorsement, recommendation, or favoring by the U.S. Government or any agency thereof. The views and opinions of authors expressed herein do not necessarily state or reflect those of the U.S. Government or any agency thereof. 
INL/EXT-16-38280

\title{
AGR-3/4 Irradiation Test Predictions using PARFUME
}

\author{
William F. Skerjanc
}

March 2016

\begin{abstract}
Idaho National Laboratory
INL ART Program

Idaho Falls, Idaho 83415
\end{abstract}

http://www.inl.gov

Prepared for the

U.S. Department of Energy

Office of Nuclear Energy

Under DOE Idaho Operations Office

Contract DE-AC07-05ID14517 

INL ART Program

\section{AGR-3/4 Irradiation Test Predictions using PARFUME}

INL/EXT-38280

March 2016

Author:
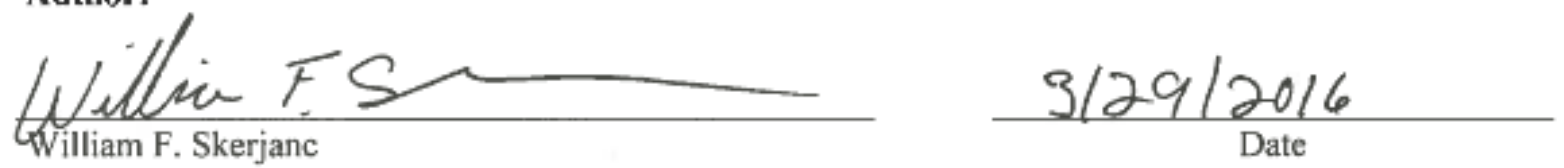

Reviewed by:
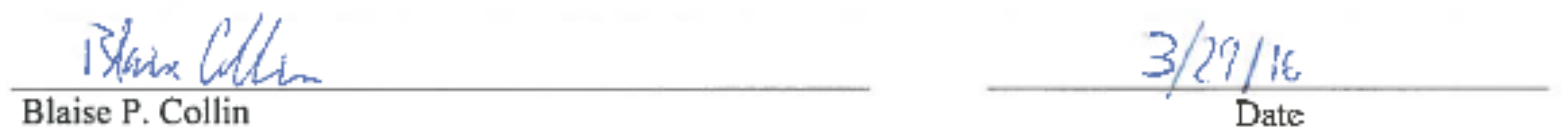

Approved by:

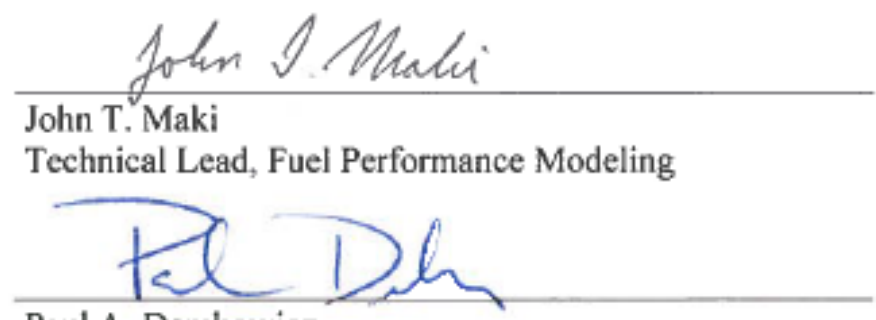

Paul A. Demkowicz

$\frac{3-29-16}{\text { Date }}$

Fuels Post-Irradiation Examination Technical Lead

$\frac{3 / 29 / 16}{\text { Date }}$

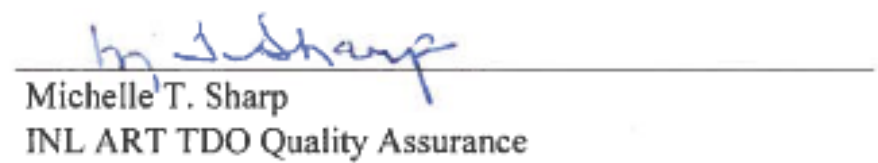

$\frac{3 / 22 / 16}{\text { Date }}$




\section{ABSTRACT}

PARFUME, (PARticle FUel ModEl) a fuel performance modeling code used for high temperature gas-cooled reactors (HTGRs), was used to model the Advanced Gas Reactor (AGR)-3/4 irradiation test using as-run physics and thermal hydraulics data. The AGR-3/4 test consists of the combined third and fourth planned irradiations of the AGR Fuel Development and Qualification Program. The AGR-3/4 test train consists of twelve separate and independently controlled and monitored capsules. Each capsule contains four compacts filled with both uranium oxycarbide (UCO) unaltered "driver" fuel particles and UCO designed-to-fail (DTF) fuel particles. The DTF fraction was specified to be $1 \times 10^{-2}$. This report documents the calculations performed to predict the failure probability of tristructural isotropic (TRISO) coated driver fuel particles during the AGR-3/4 experiment. In addition, this report documents the calculated source term from both the driver fuel and DTF particles. The calculations include the modeling of the AGR-3/4 irradiation that occurred from December 2011 to April 2014 in the Advanced Test Reactor (ATR) over a total of ten ATR cycles including seven normal cycles, one low power cycle, one unplanned outage cycle, and one Power Axial Locator Mechanism cycle.

Results show that failure probabilities are predicted to be low, resulting in zero driver fuel particle failures per capsule. The primary fuel particle failure mechanism occurred as a result of localized stresses induced by the calculated IPyC cracking. Assuming 1,872 driver fuel particles per compact, failure probability calculated by PARFUME leads to no predicted particle failure in the AGR-3/4 driver fuel.

In addition, the release fraction of fission products, silver (Ag), cesium (Cs), and strontium (Sr) were calculated to vary depending on capsule location and irradiation temperature. The maximum release fraction of Ag occurs in Capsule 7, reaching up to 50\% for the driver fuel and $100 \%$ for the DTF fuel. The release fraction of the other two fission products, Cs and Sr, are much smaller and, in most cases, less than $1 \%$ for the driver fuel. The notable exception occurs in Capsule 7, where the release fraction for Cs and $\mathrm{Sr}$ reach up to $0.73 \%$ and $2.4 \%$, respectively, for the driver fuel. For the DTF fuel in Capsule 7 , the release fraction for $\mathrm{Cs}$ and $\mathrm{Sr}$ are estimated to be $100 \%$ and $4.9 \%$, respectively. 


\section{CONTENTS}

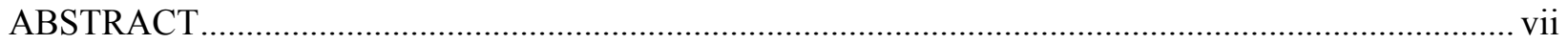

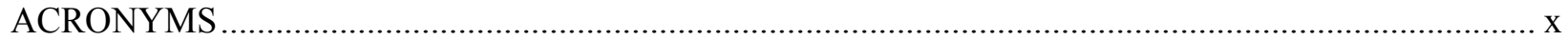

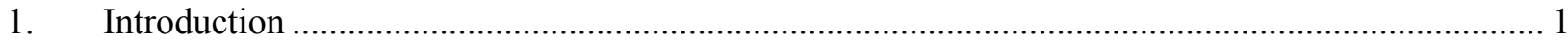

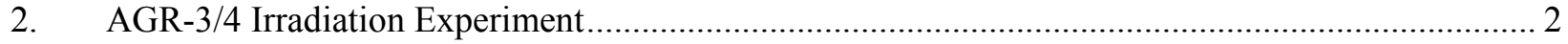

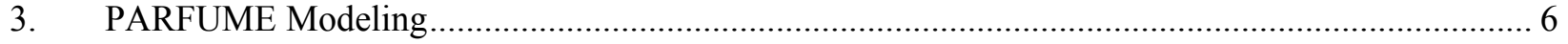

3.1 Boundary/Irradiation Conditions ................................................................................ 6

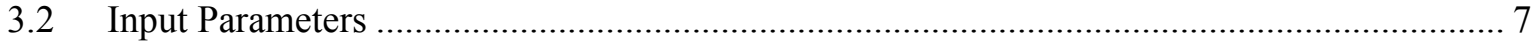

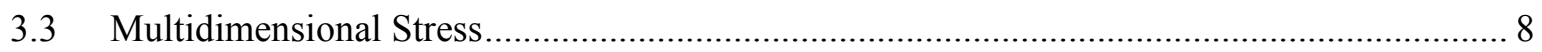

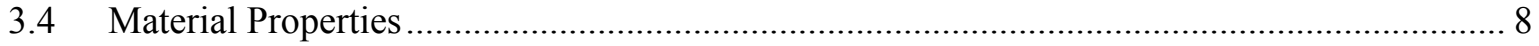

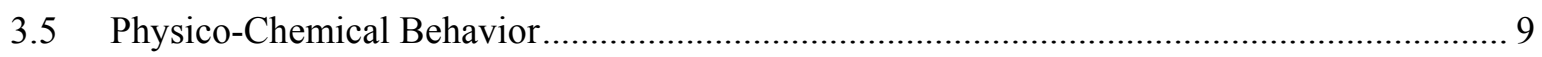

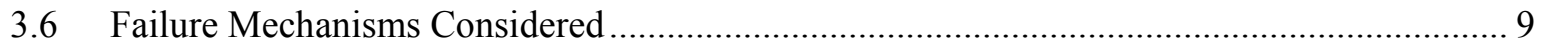

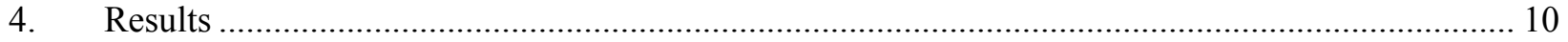

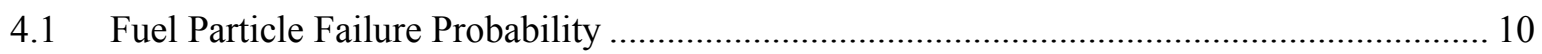

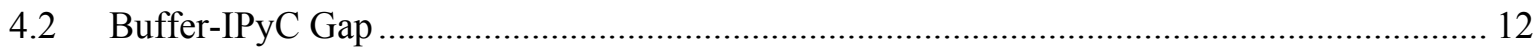

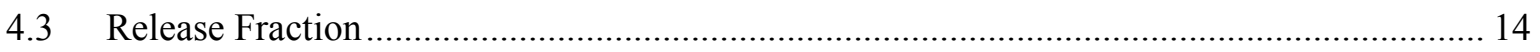

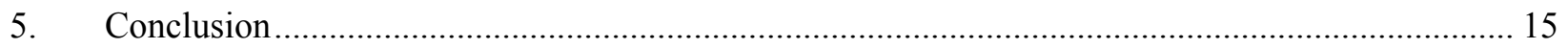

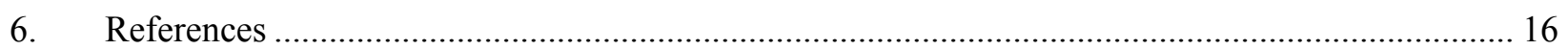

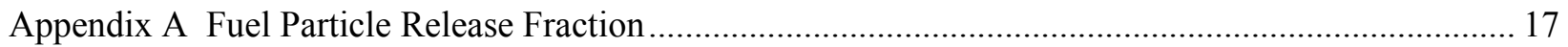




\section{FIGURES}

Figure 1. ATR core cross section displaying the NEFT position..............................................................2

Figure 2. Axial schematic of the AGR-3/4 capsules................................................................................. 3

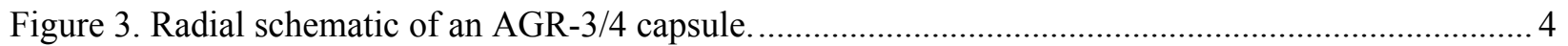

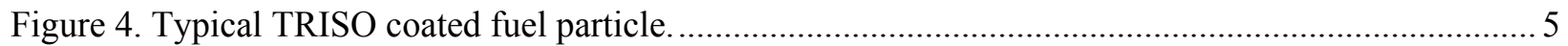

Figure 5. Schematic of an AGR-3/4 compact with DTF fuel particles along the axis..............................5

Figure 8. Particle temperature differentials (from the kernel centerline to the outer surface of the

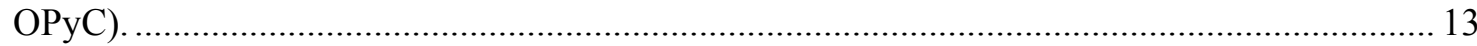

\section{TABLES}

Table 1. Capsule thermal conditions and end-of-irradiation burnup and fluence (369.1 EFPD)................ 7

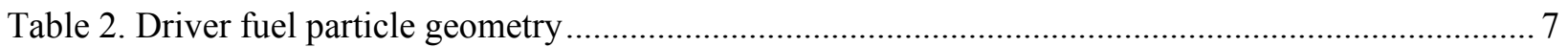

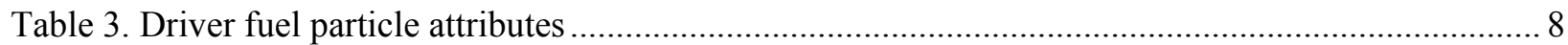

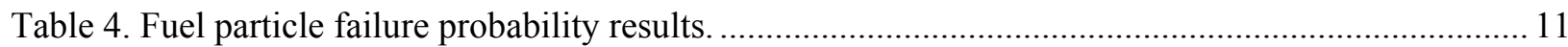

Table 5. Average fractional release by particles (1,872 driver fuel, 20 DTF) ...................................... 14

Table A1. Summary of inventory (number of atoms) released by the particles (1,872 driver fuel,

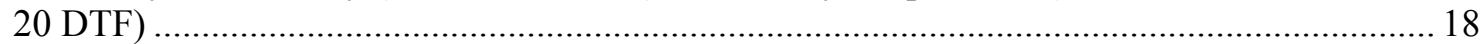

Table A2. Summary of fractional release by the particles (1,872 driver fuel, 20 DTF) ........................ 19 


\section{ACRONYMS}

AGR Advanced Gas Reactor

AGR-1 first irradiation test of the AGR program

AGR-3/4 third/fourth irradiation test of the AGR program

ART Advanced Reactor Technologies

ATR Advanced Test Reactor

BAF Bacon Anisotropy Factor

BWXT BWX Technologies

DTF designed-to-fail

EFPD effective full power days

FIMA fissions per initial heavy metal atom

HTGR high temperature gas-cooled reactor

INL Idaho National Laboratory

IPyC inner pyrolytic carbon

LEU low enriched uranium

NEFT northeast flux trap

OPyC outer pyrolytic carbon

PALM Power Axial Locator Mechanism

PARFUME PARticle FUel ModEl

PIE post-irradiation examination

PyC pyrolytic carbon

$\mathrm{R} / \mathrm{B} \quad$ release rate to birth rate ratio

$\mathrm{SiC} \quad$ silicon carbide

TDO Technology Development Office

TRISO TRistructural ISOtropic

UCO uranium oxycarbide 


\section{Introduction}

Several fuel and material irradiation experiments have been planned for the Idaho National Laboratory's (INL) Advanced Reactor Technologies (ART) Technology Development Office (TDO) Advanced Gas Reactor (AGR) Fuel Development and Qualification Program (referred to as the INL ART TDO/AGR fuel program hereafter). These experiments support development and qualification of tristructural isotropic (TRISO)-coated particle fuel for use in high-temperature gas-cooled reactors (HTGRs). The goals of these experiments are to provide irradiation performance data to support fuel process development, qualify fuel for normal operating conditions, support development and validation of fuel performance and fission product transport models and codes, and provide irradiated fuel and materials for post-irradiation examination (PIE) and safety testing (INL 2015). AGR-3/4 combined the third and fourth in this series of planned experiments to test TRISO-coated, low enriched uranium (LEU) oxycarbide (UCO) fuel.

The AGR-3/4 fuel test has been successfully completed and the results are presented in the AGR-3/4 Irradiation Test Final As-Run Report (Collin 2015). Final burnup values on a per compact basis ranged from 4.85 to $15.27 \%$ fissions per initial heavy metal atom (FIMA), while fast fluence values ranged from 1.19 to $5.32 \times 10^{25} \mathrm{n} / \mathrm{m}^{2}\left(\mathrm{E}_{\mathrm{n}}>0.18 \mathrm{MeV}\right)$. Time-average/volume-average fuel temperatures on a capsule basis at the end of irradiation ranged from $845^{\circ} \mathrm{C}$ in Capsule 12 to $1276^{\circ} \mathrm{C}$ in Capsule 7.

This report documents the calculations performed to predict the failure probability of TRISO-coated fuel particles during the AGR-3/4 experiment. In addition, this report documents the calculated source term from both the driver fuel and design-to-fail (DTF) particles. The calculations include modeling of the AGR-3/4 irradiation that occurred from December 2011 to April 2014 in the Advanced Test Reactor (ATR) over a total of ten ATR cycles, including seven normal cycles, one low-power cycle, one unplanned outage cycle, and one Power Axial Locator Mechanism (PALM) cycle for a total of 369.1 effective full power days (EFPD). Because no burnup was accumulated during the low-power cycle and the AGR-3/4 test train was moved to the ATR canal during the unplanned outage and PALM cycles, the modeling covers only the seven normal power cycles.

The modeling was performed using the PARticle FUel ModEl (PARFUME) computer code developed at INL. PARFUME is an advanced gas-cooled reactor fuel performance modeling and analysis code (Miller et al. 2009). It has been developed as an integrated mechanistic code that evaluates the thermal, mechanical, and physico-chemical behavior of fuel particles during irradiation to determine the failure probability of a population of fuel particles. It factors the particle-to-particle statistical variations in physical dimensions and the material properties that arise from the fuel fabrication process, accounting for most viable mechanisms that can lead to particle failure. The code also determines the diffusion of fission products from the fuel through the particle coating layers and through the fuel matrix to the coolant boundary. The subsequent release of fission products is calculated at the compact level (i.e., release of fission products from the compact). PARFUME calculates the release fraction as a ratio of the number of atoms released from the compact to the amount produced in the compact fuel kernels and through uranium contamination.

Calculations were performed with PARFUME Version 2.23 (as configured by the Revision Control System) compiled with Intel FORTRAN Compiler 11.1.073 on an SGI Altix ICE 8200 platform operating under SUSE Linux Enterprise Server 10. PARFUME was executed with its Fast Integration scheme to calculate the particle failure probabilities and with its Monte Carlo scheme to obtain the fractional releases of fission products. In addition, this study was conducted in accordance to quality standard NQA1-2008/-1a-2009 “Quality Assurance Requirements for Nuclear Facility Applications," published by the American Society of Mechanical Engineers (ASME 2008).

Details associated with completing these calculations are provided in the remainder of this document. The AGR-3/4 irradiation experiment description is briefly introduced in Section 2, PARFUME modeling 
is outlined in Section 3, results are described in Section 4, conclusions are given in Section 5, and references are listed in Section 6.

\section{AGR-3/4 Irradiation Experiment}

As defined in the Technical Program Plan for the INL ART TDO/AGR fuel program (INL 2015), the objectives of the AGR-3/4 experiment are as follows:

1. Irradiate fuel containing UCO DTF fuel particles that will provide a known source of fission products for subsequent transport through compact matrix and structural graphite materials.

2. Assess the effects of sweep gas impurities (such as $\mathrm{CO}, \mathrm{H}_{2} \mathrm{O}$, and $\mathrm{H}_{2}$ ) that are typically found in the primary coolant circuit of HTGRs, on fuel performance and subsequent fission product transport.

3. Provide irradiated fuel and material samples for post-irradiation examination and safety testing.

4. Support the refinement of fuel performance and fission product transport models with online, PIE and safety test data.

To achieve the test objectives outlined above, in accordance with requirements from the Technical Program Plan (INL 2015) and the Irradiation Test Specification (Maki 2011), AGR-3/4 was irradiated in the northeast flux trap (NEFT) position of the ATR at INL. A cross-sectional view of the ATR core, which indicates the NEFT location, is displayed in Figure 1.

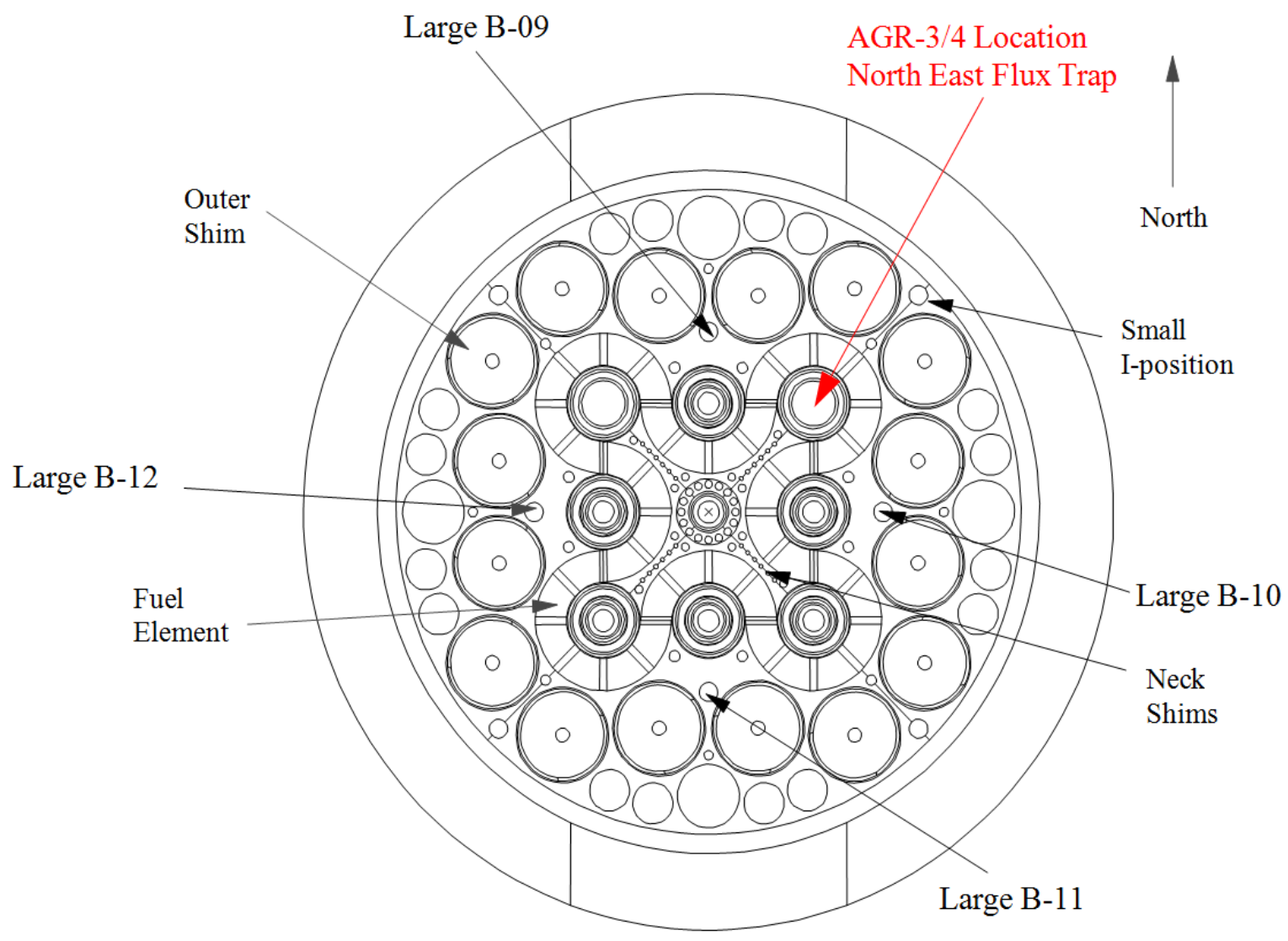

Figure 1. ATR core cross section displaying the NEFT position. 
The AGR-3/4 test train is a multi-capsule, instrumented experiment that is designed for irradiation in the 133.4-mm diameter NEFT position of ATR. The best geometry for obtaining fission product transport data was determined to be a capsule that consists of a single stack of fuel compacts that contain a known fraction of DTF particles surrounded by three concentric annular rings of test material: (1) an annulus of fuel-compact matrix material; (2) an annulus of fuel-element graphite; and (3) an annulus of graphite operating at a lower temperature to act as a sink for fission products. This configuration best reduces axial thermal gradients and, hence, axial diffusion. The test reactor's axial flux distribution and space considerations within the test train impose a practical limit of twelve independently controlled and monitored capsules per test train. An axial view of the test train is illustrated in Figure 2. Figure 3 illustrates the radial view of a capsule.

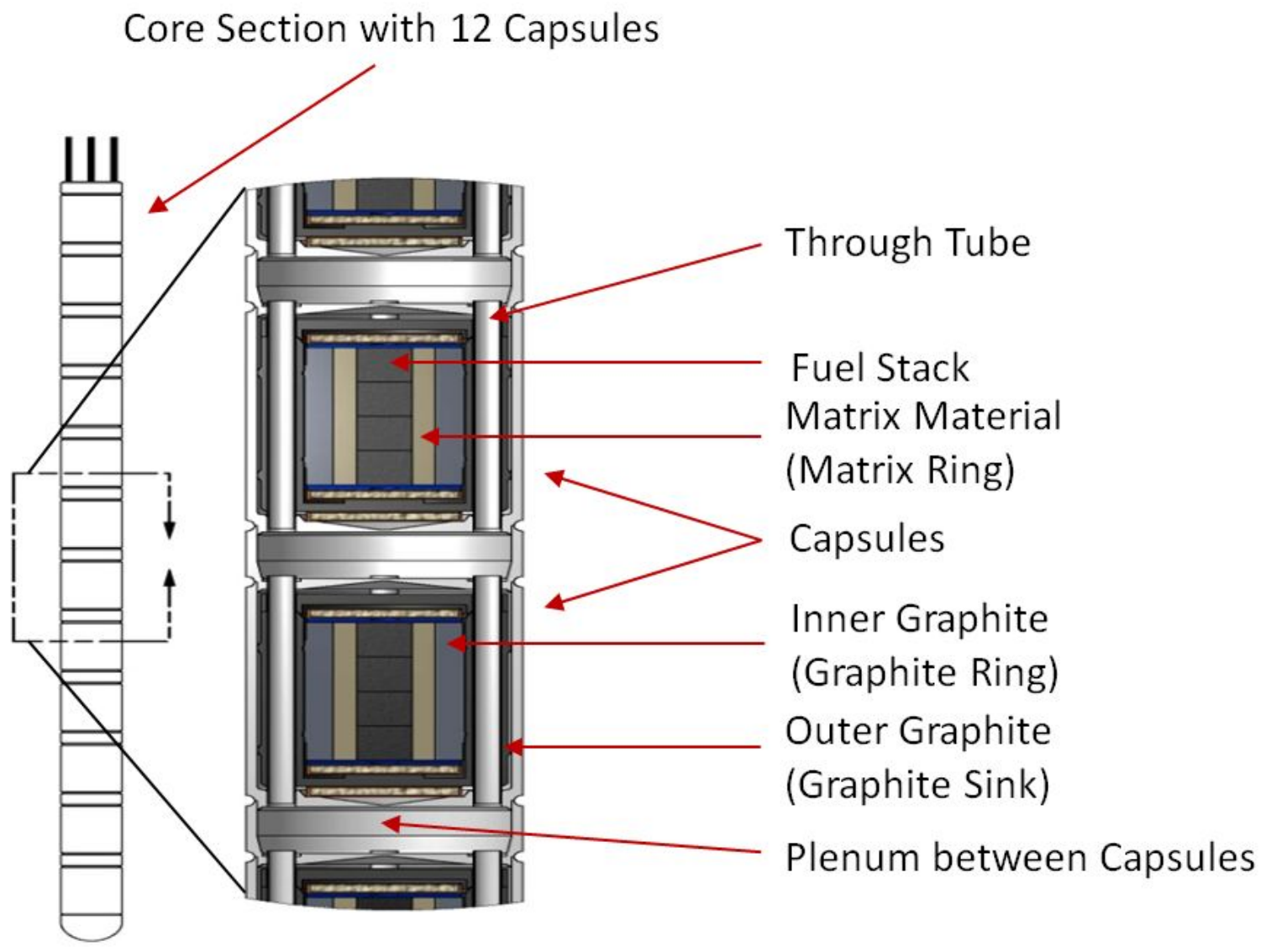

Figure 2. Axial schematic of the AGR-3/4 capsules. 


\section{Through Tubes with TCs and Gas Lines}

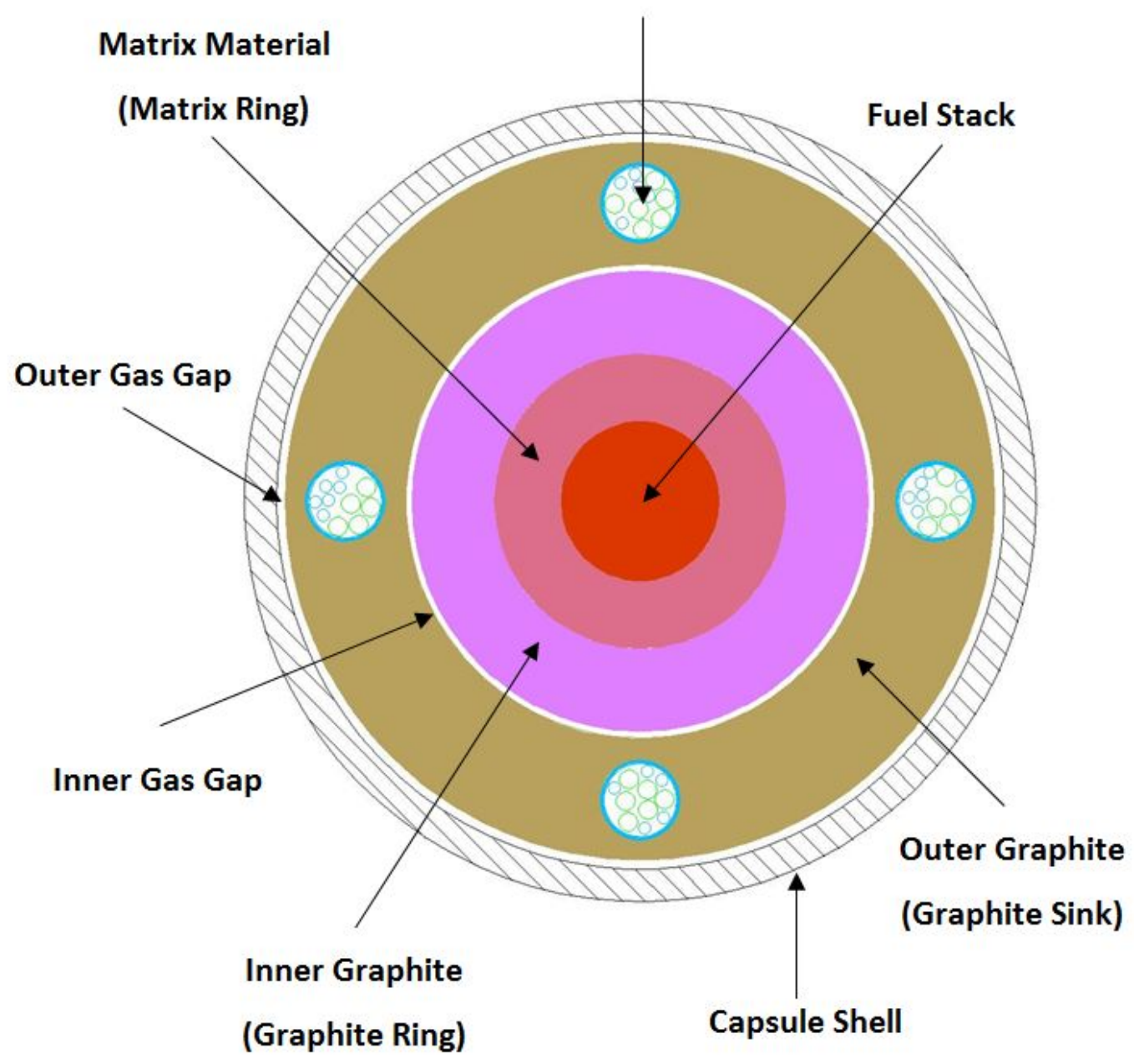

Figure 3. Radial schematic of an AGR-3/4 capsule.

Fuel for AGR-3/4 contains conventional driver fuel that is similar to the baseline fuel used in the AGR-1 experiment (Barnes 2006a) and the DTF fuel particles whose kernels are identical to the driver fuel kernels and whose coatings are designed to fail under irradiation, leaving fission products to migrate through the surrounding materials (Barnes 2006b; Marshall 2011):

- Driver fuel consists of TRISO-coated particles that are slightly less than $1 \mathrm{~mm}$ in diameter. Each particle has a central reference kernel that contains fuel material, a porous carbon buffer layer, an inner pyrolytic carbon (IPyC) layer, a silicon carbide $(\mathrm{SiC})$ barrier coating, and an outer pyrolytic carbon $(\mathrm{OPyC})$ layer as depicted in Figure 4.

- $\quad$ DTF fuel consists of reference kernels with a 20- $\mu \mathrm{m}$ thick pyrolytic carbon (PyC) seal coating. This coating was designed to fail early in the irradiation and provide a known source of fission products. 


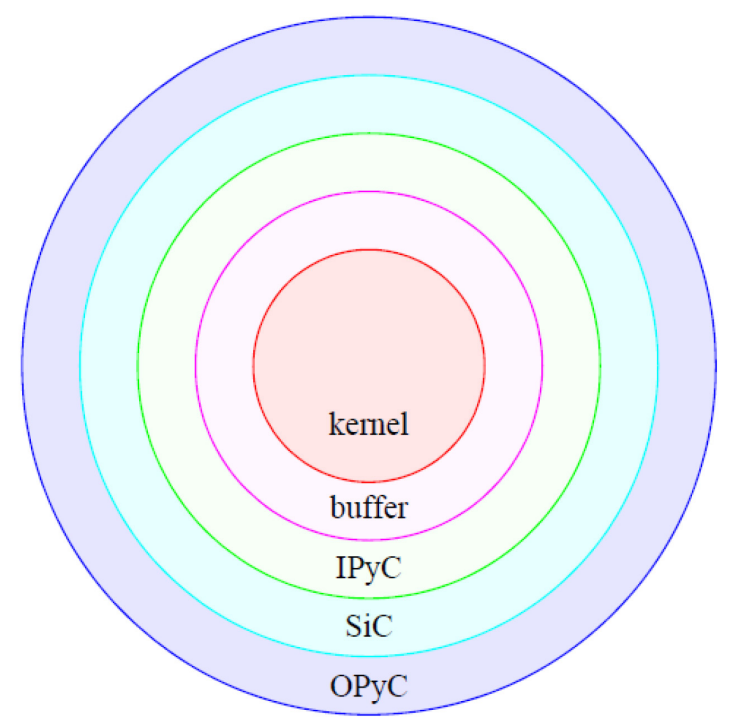

Figure 4. Typical TRISO coated fuel particle.

Kernels for AGR-3/4 consist of LEU UCO fuel. The kernels were fabricated by BWX Technologies (BWXT 2006) in accordance with the AGR-3/4 Fuel Product Specification (Marshall 2011). The UCO kernels were coated and characterized by Oak Ridge National Laboratory (Hunn 2007; Hunn 2011). Coating was performed in accordance with the AGR-3/4 Fuel Product Specification (Barnes 2006a; Marshall 2011).

After coating, AGR-3/4 fuel was formed into right cylindrical compacts. The compact matrix material is composed of a thermosetting carbonaceous material. Prior to compacting, the fuel particles were overcoated with thick layers of the compact matrix material. This overcoat is intended to prevent particleto-particle contact and help achieve the desired packing fraction of the fuel particles. Each AGR-3/4 compact contains driver fuel particles and 20 DTF particles (about $1 \%$ of the particles) that are placed along its axis (Figure 5). AGR-3/4 compacts are nominally $12.51 \mathrm{~mm}$ in length and $12.31 \mathrm{~mm}$ in diameter. A complete description of the fuel compacts, fission product monitoring system, physics analysis, and thermal analysis are presented in the final as-run report (Collin 2015).

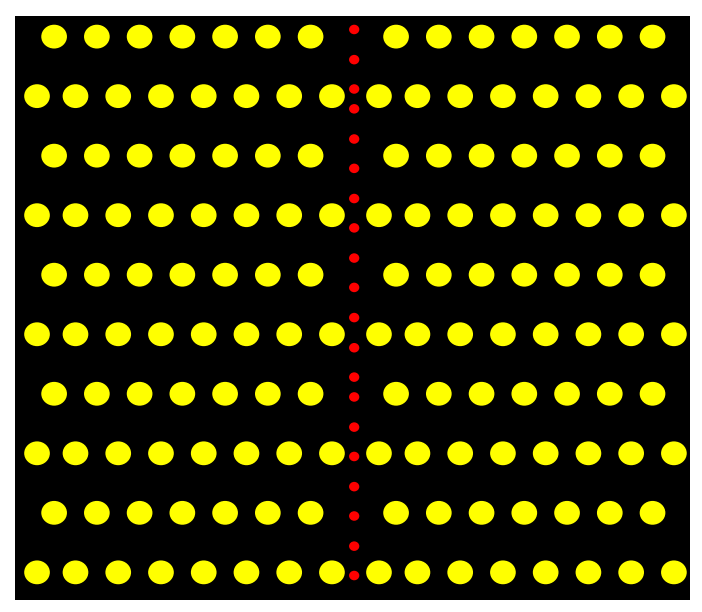

Figure 5. Schematic of an AGR-3/4 compact with DTF fuel particles along the axis. 


\section{PARFUME Modeling}

Using the data collected in the final as-run report (Collin 2015), PARFUME was used to model the AGR-3/4 experiment to determine the probability of fuel particle failure and the release fractions of the fission products silver $(\mathrm{Ag})$, cesium $(\mathrm{Cs})$, and strontium $(\mathrm{Sr})$ to determine the source term for both the driver and DTF fuels. The analysis considered conventional fuel particle failure (i.e., typical pressure vessel failure) and multidimensional failure mechanisms (i.e., IPyC cracking, asphericity, and debonding). The source terms were calculated assuming no failures of driver fuel and failure of the DTF particles at time equal to zero. Key aspects of the PARFUME modeling of these AGR-3/4 conditions are described in the following subsections.

\subsection{Boundary/Irradiation Conditions}

PARFUME is designed to evaluate fuel performance based on user inputs for neutron fluence and burnup, with a corresponding set of thermal conditions. Results from neutronics analyses and/or measured values are possible sources for fluence and burnup inputs. For this analysis, capsule-specific fluence and burnup results from neutronics analyses performed as part of the AGR-3/4 final as-run report were used as shown in Table 1.

PARFUME has considerable flexibility relative to the application of thermal conditions affecting fuel particles. A user may define the thermal conditions for the outer surfaces of the fuel bearing materials (e.g., the outer surface of a pebble in the case of a pebble bed reactor or the coolant channel surface of a unit cell containing fuel compacts in the case of a prismatic reactor) or the user may define fuel bearing material temperatures directly. Options for the outer surfaces of the fuel bearing materials include defining either a time-dependent set of temperatures or a time-dependent set of heat transfer coefficients, with a corresponding time-dependent set of sink temperatures. Fuel-bearing material temperatures can be defined directly as time-dependent values that are applicable to the entire material or the user may divide the material into regions and supply time-dependent temperatures for each region. The direct specification of fuel-bearing material temperatures was applied here.

For the purpose of calculating the fuel failure probability, three types of capsule-specific PARFUME calculations were completed with respect to the temperature data specified in Table 1. Specifically, calculations were made assuming that each of the twelve capsules followed a constant maximum temperature, time average/volume average temperature, and minimum temperature throughout the entire irradiation. Note that all driver fuel particles (in a given capsule) share the same outer (OPyC) surface temperature in these calculations.

The modeling of fission product release was made on a compact basis; therefore, its results could be used as a source term to support the PIE effort on fission product transport in the AGR-3/4 rings. Rather than using time average temperatures, more accurate results were obtained using the compact volume average daily temperatures from thermal hydraulics analysis. Furthermore, the driver fuel was assumed to stay intact (i.e., no particle failures were assumed) in accordance with the failure probability calculations. 
Table 1. Capsule thermal conditions and end-of-irradiation burnup and fluence (369.1 EFPD).

\begin{tabular}{|l|l|l|l|l|l|}
\hline \multirow{2}{*}{ Capsule } & \multirow{2}{*}{$\begin{array}{l}\text { Average } \\
\text { Burnup } \\
(\% \text { FIMA })\end{array}$} & $\begin{array}{l}\text { Average Fluence } \\
\left(\mathrm{x} 10^{25} \mathrm{n} / \mathrm{m}^{2}\right) \\
{\left[\mathrm{E}_{\mathrm{n}}>0.18 \mathrm{MeV}\right]}\end{array}$ & $\begin{array}{l}\text { Temperature }\left({ }^{\circ} \mathrm{C}\right) \\
\text { Time-Average } \\
\text { Minimum }\end{array}$ & $\begin{array}{l}\text { Time-Average } \\
\text { Volume- } \\
\text { Average }\end{array}$ & $\begin{array}{l}\text { Time-Average } \\
\text { Maximum }\end{array}$ \\
\hline 12 & 5.35 & 1.50 & 781 & 845 & 879 \\
\hline 11 & 9.06 & 2.87 & 1104 & 1193 & 1246 \\
\hline 10 & 11.80 & 3.94 & 1062 & 1169 & 1225 \\
\hline 9 & 13.67 & 4.65 & 922 & 1033 & 1099 \\
\hline 8 & 14.51 & 5.08 & 1026 & 1142 & 1207 \\
\hline 7 & 14.96 & 5.27 & 1157 & 1276 & 1341 \\
\hline 6 & 15.24 & 5.31 & 912 & 1041 & 1114 \\
\hline 5 & 14.87 & 5.19 & 868 & 1018 & 1095 \\
\hline 4 & 14.21 & 4.85 & 908 & 1036 & 1107 \\
\hline 3 & 12.58 & 4.22 & 1023 & 1150 & 1213 \\
\hline 2 & 10.07 & 3.21 & 940 & 1039 & 1092 \\
\hline 1 & 6.14 & 1.76 & 807 & 915 & 964 \\
\hline
\end{tabular}

\subsection{Input Parameters}

PARFUME input parameters for modeling the AGR-3/4 experiment were taken from the Fuel Product Specification (Marshall 2011). The fuel particle geometry and material properties are listed in Tables 2 and 3, respectively.

The Abaqus calculations were made using an asphericity of 1.056 that corresponds to the sphericity at the OPyC level. There was no measurement of the sphericity at the $\mathrm{SiC}$ level, which is the determining factor for asphericity calculations. Therefore, the calculations over-estimated the asphericity in the Abaqus (and subsequent PARFUME) calculations. Because the failure probability from pressure is very low, this has no impact on the $\mathrm{SiC}$ failure probability.

Table 2. Driver fuel particle geometry

\begin{tabular}{|l|l|l|l|}
\hline Attribute & Units & $\begin{array}{l}\text { Mean } \\
\text { Value }\end{array}$ & $\begin{array}{l}\text { Standard } \\
\text { Deviation }\end{array}$ \\
\hline Kernel Diameter & $\mu \mathrm{m}$ & 357.3 & 10.5 \\
\hline Buffer Thickness & $\mu \mathrm{m}$ & 109.7 & 7.7 \\
\hline IPyC Thickness & $\mu \mathrm{m}$ & 40.4 & 2.3 \\
\hline SiC Thickness & $\mu \mathrm{m}$ & 33.5 & 1.1 \\
\hline OPyC Thickness & $\mu \mathrm{m}$ & 41.3 & 2.1 \\
\hline Particle Sphericity & $\mu \mathrm{m}$ & 1.056 & -- \\
\hline
\end{tabular}


Table 3. Driver fuel particle attributes

\begin{tabular}{|l|c|c|c|}
\hline \multicolumn{1}{|c|}{ Attribute } & Units & $\begin{array}{c}\text { Mean } \\
\text { Value }\end{array}$ & $\begin{array}{c}\text { Standard } \\
\text { Deviation }\end{array}$ \\
\hline Kernel Density & $\mathrm{Mg} / \mathrm{m}^{3}$ & 11.10 & -- \\
\hline Buffer Density & $\mathrm{Mg} / \mathrm{m}^{3}$ & 1.10 & -- \\
\hline IPyC Density & $\mathrm{Mg} / \mathrm{m}^{3}$ & 1.904 & 0.014 \\
\hline OPyC Density & $\mathrm{Mg} / \mathrm{m}^{3}$ & 1.901 & 0.012 \\
\hline IPyC BAF & & 1.027 & 0.002 \\
\hline OPyC BAF & & 1.021 & 0.002 \\
\hline PyC Poisson's Ratio in Creep & & 0.5 & -- \\
\hline U-235 Enrichment & weight \% & 19.717 & -- \\
\hline Oxygen-to-Uranium & atom ratio & 1.430 & -- \\
\hline Carbon-to-Uranium & atom ratio & 0.361 & -- \\
\hline
\end{tabular}

\subsection{Multidimensional Stress}

In addition to the one-dimensional behavior of a symmetrical spherical fuel particle, PARFUME considers multidimensional behavior, including: 1) aspherical geometry; 2) cracking of the IPyC layer; and 3) partial debonding of the IPyC from the SiC. To model these effects, PARFUME uses the results of detailed finite element analyses for cracked, debonded, and/or aspherical particles in conjunction with results from the PARFUME, closed form, one-dimensional solution to make a statistical approximation of the stress levels in any particle (Miller et al. 2003; Miller et al. 2004). Abaqus Version 6.9-2 (Abaqus 2009) was used to perform the finite element stress analyses to capture the multidimensional effects of asphericity and IPyC cracking. It has been previously determined that variations in parameters that greatly impact the multidimensional results include the IPyC, SiC, and OPyC thicknesses for both IPyC cracking and asphericity along with the aspect ratio for asphericity (Skerjanc et al. 2016). IPyC/SiC debonding was not considered in this analysis because current fuel manufacturing practices have greatly improved the $\mathrm{IPyC} / \mathrm{SiC}$ bond strength (about $100 \mathrm{MPa}$ ), resulting in zero fuel particle failures due to debonding as calculated by PARFUME.

\subsection{Material Properties}

Material properties used in PARFUME are discussed in great detail in the PARFUME Theory Manual (Miller et al. 2009). The elastic moduli and swelling strains for the IPyC and OPyC are treated as functions of fluence. The effective range for these properties extends to a fluence of $3.96 \times 10^{25} \mathrm{n} / \mathrm{m}^{2}$. However, an approximation was necessary to enable PARFUME modeling of some capsules in the AGR$3 / 4$ test where the end-of-life fluence reaches as much as $5.31 \times 10^{25} \mathrm{n} / \mathrm{m}^{2}$. The approximation consists of treating the elastic moduli and swelling strain rates as constants in PARFUME beyond a fluence level of $3.96 \times 10^{25} \mathrm{n} / \mathrm{m}^{2}\left(\mathrm{E}_{\mathrm{n}}>0.18 \mathrm{MeV}\right)$.

The historical creep coefficient for the pyrocarbon layers (CEGA 1993) was found to be significantly lower than what has been used in other fuel performance models. It has also been found that PARFUME gives favorable comparisons with results of the New Production - Modular High Temperature Gas Reactor (NPMHTGR) experiments if the historical creep coefficient is approximately doubled (Miller et al. 2003). Therefore, the creep coefficient used in predictions for the AGR-3/4 test was set equal to twice the historical value. 
There is significant uncertainty in how well the physical properties of the coating layers are known (Martin 2002). The accuracy of the failure probability predictions from any fuel performance code relies on the accuracy of these properties.

\subsection{Physico-Chemical Behavior}

The internal gas pressure is calculated in PARFUME as a function of time according to the Redlich-Kwong equation of state. Parameters utilized in this equation are derived from the critical temperature and pressure of each gas species occupying the void volume within the particle. PARFUME considers generation of carbon monoxide and release of the noble gas fission products (i.e., xenon and krypton) in this pressure calculation.

Carbon monoxide production is calculated in PARFUME using an algorithm derived from thermochemical free energy minimization calculations performed by the HSC computer code. PARFUME calculates fission product gas release caused by both recoil and diffusion. Direct fission recoil from the kernel to the buffer is accounted for by geometrical considerations and fission fragment ranges derived from compiled experimental data. Diffusive release is calculated according to the Booth equivalent sphere diffusion model, which utilizes an effective diffusion coefficient formulated by Turnbull. This effective diffusion coefficient accounts for intrinsic, thermal, and irradiation-enhanced diffusion.

A complete description of the treatment of the physico-chemical behavior can be found in the PARFUME Theory Manual (Miller et al. 2009).

\subsection{Failure Mechanisms Considered}

Four potential failure mechanisms are currently considered in PARFUME. The first is a pressure vessel failure caused by buildup of gases (e.g. fission, CO). Stresses for this failure mechanism are determined using the one-dimensional solution in PARFUME for a three-layer (IPyC-SiC-OPyC) particle. Because of asphericity in the particle shape, these stresses are modified based on the results of the finite element analysis of aspherical particles. Some particles' internal pressures were found to trigger this failure mechanism in AGR-3/4 test calculations.

The second mechanism considered is failure of the $\mathrm{SiC}$ layer caused by partial debonding of the IPyC from the SiC. Debonding, if it occurs, results from the IPyC shrinking inward away from the SiC during irradiation. PARFUME first determines whether debonding between the layers occurs by comparing the radial stress between layers with the bond strength between layers. If debonding is determined to occur, then the code estimates the stress in the $\mathrm{SiC}$ layer and accounts for the multidimensional effects using a previously documented methodology. Because AGR-3/4 particle fabrication was based on German processes, the bond strength was set at a value that is considered to be representative for German particles (i.e., $100 \mathrm{MPa}$ ). At this bond strength, $\mathrm{IPyC} / \mathrm{SiC}$ debonding was not predicted; therefore, debonding did not contribute to particle failures in the AGR-3/4 test.

The third failure mechanism considered in PARFUME is migration of the fuel kernel into the $\mathrm{SiC}$ layer under the influence of a temperature gradient (or the amoeba effect). This effect is driven by the production of carbon monoxide and is only prominent with $\mathrm{UO}_{2}$ kernels and is limited with UCO kernels. Therefore, the amoeba effect made no contribution to particle failures in these analyses.

The fourth and final failure mechanism currently considered in PARFUME is failure of the SiC layer caused by irradiation-induced shrinkage and the associated cracking of the IPyC layer. The presence of a crack in the IPyC layer creates a stress concentration in the SiC layer. To treat the multidimensional effects of this stress concentration, PARFUME estimates stresses in the SiC layer that result from the presence of a crack based on a previously documented methodology. In evaluating failures caused by IPyC cracking, PARFUME first determines whether the IPyC layer cracks using the Weibull statistical theory. If the IPyC layer is predicted to crack, the particle is evaluated for failure of the SiC layer due to 
the presence of the crack. Some fuel particle failure probability results in AGR-3/4 test calculations were found to be caused by this mechanism.

Chemical attack of the $\mathrm{SiC}$ layer by palladium $(\mathrm{Pd})$ represents another potential failure mechanism. Scoping calculations have shown that fuel particle failure occurs when penetration through the thickness of the $\mathrm{SiC}$ is complete, leading to the direct release of fission products. However, based on Pd penetration rates, $\mathrm{SiC}$ failure would not be predicted to occur in the AGR-3/4 test even if particle temperatures were assumed to remain fixed at the maximum calculated value for the entire irradiation period.

PARFUME uses the Weibull statistical theory to determine whether particles fail, using a mean strength for the $\mathrm{SiC}$ layer based on a stress distribution corresponding to the failure mechanism under consideration. The failure modes are implemented such that a particle fails only in the mode of failure that would occur first for that particle. The code retains the time at which the failures occur, allowing for construction of a time evolution of the failure probability for a batch of fuel particles. Weibull parameters that are used to evaluate failures of the $\mathrm{SiC}$ layer and cracking of the IPyC layer are discussed in the CEGA report (CEGA 1993).

\section{Results}

Results from the AGR-3/4 test predictions were obtained using PARFUME and are based on the inputs and modeling parameters discussed previously. These results include fuel particle failure probability, buffer-IPyC gap formation, and fission product release fractions. The results of particle failure probability were obtained using the fast (i.e., 2-loop) integration solver implemented in PARFUME as opposed to the full-loop integration or Monte Carlo method; this is due to the significant reduction in run times. It has been previously been demonstrated that using the fast integration method does not adversely impact the accuracy of the results (Miller and Knudson 2007). The fission product release calculations were run using the Monte Carlo scheme of PARFUME.

\subsection{Fuel Particle Failure Probability}

It is assumed that a fuel particle has failed when the $\mathrm{SiC}$ layer has become compromised and cracked, which leads to its inability to retain fission products. The primary mechanisms leading to $\mathrm{SiC}$ cracking and subsequent fuel particle failure in the AGR-3/4 analyses are due to IPyC cracking and pressure. In addition, it was also determined that no fuel particle failure was predicted due to the amoeba effect or $\mathrm{IPyC} / \mathrm{SiC}$ debonding. Complete results for the fuel particle failure probability analyses for the AGR-3/4 test are summarized in Table 4 and illustrated in Figure 6. Assuming 1,872 driver fuel particles per compact, PARFUME predicted zero fuel particle failures in all 12 capsules at the three temperature conditions specified. In general, the probability of driver fuel particle failure can be mostly attributed to IPyC cracking. The primary driver of pressure-related failures is due to the production of $\mathrm{CO}$, which is minimized in UCO fuel. Capsule 7, at the maximum temperature, experienced the largest Pd penetration into the $\mathrm{SiC}$ layer of $17.4 \mu \mathrm{m}$, which is much less than the actual SiC layer thickness $(33.5 \mu \mathrm{m})$; therefore, there is no predicted failure due to chemical attack. 
Table 4. Fuel particle failure probability results.

\begin{tabular}{|c|c|c|c|c|c|c|c|c|}
\hline \multirow[b]{3}{*}{ Capsule } & \multirow{3}{*}{\begin{tabular}{|c|} 
Temperature \\
Condition
\end{tabular}} & \multirow{3}{*}{$\begin{array}{c}\text { Temperature } \\
\left({ }^{\circ} \mathrm{C}\right)\end{array}$} & \multirow{3}{*}{\begin{tabular}{|c}
$\begin{array}{c}\text { EOL Fluence } \\
\left(x 10^{25} \mathrm{n} / \mathrm{m}^{2}\right) \\
{\left[\mathrm{E}_{\mathrm{n}}>0.18 \mathrm{MeV}\right]}\end{array}$ \\
\end{tabular}} & \multirow{3}{*}{$\begin{array}{c}\text { EOL } \\
\text { Burnup } \\
\text { (\% FIMA) }\end{array}$} & \multicolumn{3}{|c|}{ Probability of } & \multirow{3}{*}{$\begin{array}{c}\text { Estimated No. } \\
\text { of Particle } \\
\text { Failures }\end{array}$} \\
\hline & & & & & \multirow[b]{2}{*}{ Failure } & \multicolumn{2}{|c|}{ Failure due to } & \\
\hline & & & & & & IPyC Cracking & Pressure & \\
\hline \multirow{3}{*}{12} & Average & 1118 & \multirow{3}{*}{1.50} & \multirow{3}{*}{5.35} & 8.3E-05 & 8.1E-05 & $2.3 \mathrm{E}-06$ & 0 \\
\hline & Maximum & 1152 & & & 4.1E-05 & 4.1E-05 & $0.0 \mathrm{E}+00$ & 0 \\
\hline & Minimum & 1054 & & & 2.3E-04 & $2.2 \mathrm{E}-04$ & $1.5 \mathrm{E}-05$ & 0 \\
\hline \multirow{3}{*}{11} & Average & 1466 & \multirow{3}{*}{2.87} & \multirow{3}{*}{9.06} & 2.3E-08 & $2.3 \mathrm{E}-08$ & $0.0 \mathrm{E}+00$ & 0 \\
\hline & Maximum & 1519 & & & 6.6E-09 & $6.6 \mathrm{E}-09$ & $0.0 \mathrm{E}+00$ & 0 \\
\hline & Minimum & 1377 & & & $1.8 \mathrm{E}-07$ & $1.8 \mathrm{E}-07$ & $0.0 \mathrm{E}+00$ & 0 \\
\hline \multirow{3}{*}{10} & Average & 1442 & \multirow{3}{*}{3.94} & \multirow{3}{*}{11.8} & $3.9 \mathrm{E}-08$ & $3.9 \mathrm{E}-08$ & $0.0 \mathrm{E}+00$ & 0 \\
\hline & Maximum & 1498 & & & 1.1E-08 & $1.1 \mathrm{E}-08$ & $5.5 \mathrm{E}-15$ & 0 \\
\hline & Minimum & 1335 & & & 4.7E-07 & 4.7E-07 & $0.0 \mathrm{E}+00$ & 0 \\
\hline \multirow{3}{*}{9} & Average & 1306 & \multirow{3}{*}{4.65} & \multirow{3}{*}{13.67} & $8.9 \mathrm{E}-07$ & $8.9 \mathrm{E}-07$ & $0.0 \mathrm{E}+00$ & 0 \\
\hline & Maximum & 1372 & & & $2.0 \mathrm{E}-07$ & $2.0 \mathrm{E}-07$ & $0.0 \mathrm{E}+00$ & 0 \\
\hline & Minimum & 1195 & & & $1.5 \mathrm{E}-05$ & $1.5 \mathrm{E}-05$ & $0.0 \mathrm{E}+00$ & 0 \\
\hline \multirow{3}{*}{8} & Average & 1415 & \multirow{3}{*}{5.08} & \multirow{3}{*}{14.51} & 7.3E-08 & 7.3E-08 & $6.0 \mathrm{E}-18$ & 0 \\
\hline & Maximum & 1480 & & & 1.6E-08 & $1.6 \mathrm{E}-08$ & $1.5 \mathrm{E}-10$ & 0 \\
\hline & Minimum & 1299 & & & 1.1E-06 & $1.1 \mathrm{E}-06$ & $0.0 \mathrm{E}+00$ & 0 \\
\hline \multirow{3}{*}{7} & Average & 1549 & & & 6.3E-09 & 3.3E-09 & 3.0E-09 & 0 \\
\hline & \begin{tabular}{|l|} 
Maximum \\
\end{tabular} & 1614 & 5.27 & 14.96 & \begin{tabular}{|l|}
$1.1 \mathrm{E}-07$ \\
\end{tabular} & 7.7E-10 & $1.1 \mathrm{E}-07$ & 0 \\
\hline & Minimum & 1430 & & & 5.1E-08 & 5.1E-08 & $2.8 \mathrm{E}-14$ & 0 \\
\hline & Average & 1314 & & & 7.4E-07 & $7.4 \mathrm{E}-07$ & $0.0 \mathrm{E}+00$ & 0 \\
\hline 6 & Maximum & 1387 & 5.31 & 15.24 & 1.4E-07 & $1.4 \mathrm{E}-07$ & $1.0 \mathrm{E}-20$ & 0 \\
\hline & Minimum & 1185 & & & $1.9 \mathrm{E}-05$ & $1.9 \mathrm{E}-05$ & $0.0 \mathrm{E}+00$ & 0 \\
\hline & Average & 1291 & & & $1.3 \mathrm{E}-06$ & $1.3 \mathrm{E}-06$ & $0.0 \mathrm{E}+00$ & 0 \\
\hline 5 & \begin{tabular}{|l|} 
Maximum \\
\end{tabular} & 1368 & 5.19 & 14.87 & \begin{tabular}{|l|}
$2.2 \mathrm{E}-07$ \\
\end{tabular} & $2.2 \mathrm{E}-07$ & $0.0 \mathrm{E}+00$ & 0 \\
\hline & Minimum & 1141 & & & 5.1E-05 & 5.1E-05 & $1.2 \mathrm{E}-16$ & 0 \\
\hline & Average & 1309 & & & 8.3E-07 & $8.3 \mathrm{E}-07$ & $5.1 \mathrm{E}-24$ & 0 \\
\hline 4 & \begin{tabular}{|l|} 
Maximum \\
\end{tabular} & 1380 & 4.85 & 14.21 & \begin{tabular}{|l|}
$1.6 \mathrm{E}-07$ \\
\end{tabular} & $1.6 \mathrm{E}-07$ & $0.0 \mathrm{E}+00$ & 0 \\
\hline & Minimum & 1181 & & & $2.1 \mathrm{E}-05$ & $2.1 \mathrm{E}-05$ & $0.0 \mathrm{E}+00$ & 0 \\
\hline & Average & 1423 & & & $6.1 \mathrm{E}-08$ & $6.1 \mathrm{E}-08$ & $0.0 \mathrm{E}+00$ & 0 \\
\hline 3 & Maximum & 1486 & 4.22 & 12.58 & \begin{tabular}{|l|}
$1.4 \mathrm{E}-08$ \\
\end{tabular} & $1.4 \mathrm{E}-08$ & $8.8 \mathrm{E}-14$ & 0 \\
\hline & Minimum & 1296 & & & $1.2 \mathrm{E}-06$ & $1.2 \mathrm{E}-06$ & $0.0 \mathrm{E}+00$ & 0 \\
\hline & Average & 1312 & & & 7.9E-07 & 7.9E-07 & $0.0 \mathrm{E}+00$ & 0 \\
\hline 2 & \begin{tabular}{|l|} 
Maximum \\
\end{tabular} & 1365 & 3.21 & 10.07 & \begin{tabular}{|l|}
$2.3 \mathrm{E}-07$ \\
\end{tabular} & $2.3 \mathrm{E}-07$ & $0.0 \mathrm{E}+00$ & 0 \\
\hline & Minimum & 1213 & & & 1.0E-05 & 1.0E-05 & $0.0 \mathrm{E}+00$ & 0 \\
\hline & Average & 1188 & & & $1.8 \mathrm{E}-05$ & $1.8 \mathrm{E}-05$ & $0.0 \mathrm{E}+00$ & 0 \\
\hline 1 & Maximum & 1237 & 1.76 & 6.14 & 5.5E-06 & 5.5E-06 & $0.0 \mathrm{E}+00$ & 0 \\
\hline & Minimum & 1080 & & & $1.5 \mathrm{E}-04$ & $1.5 \mathrm{E}-04$ & $2.6 \mathrm{E}-07$ & 0 \\
\hline
\end{tabular}




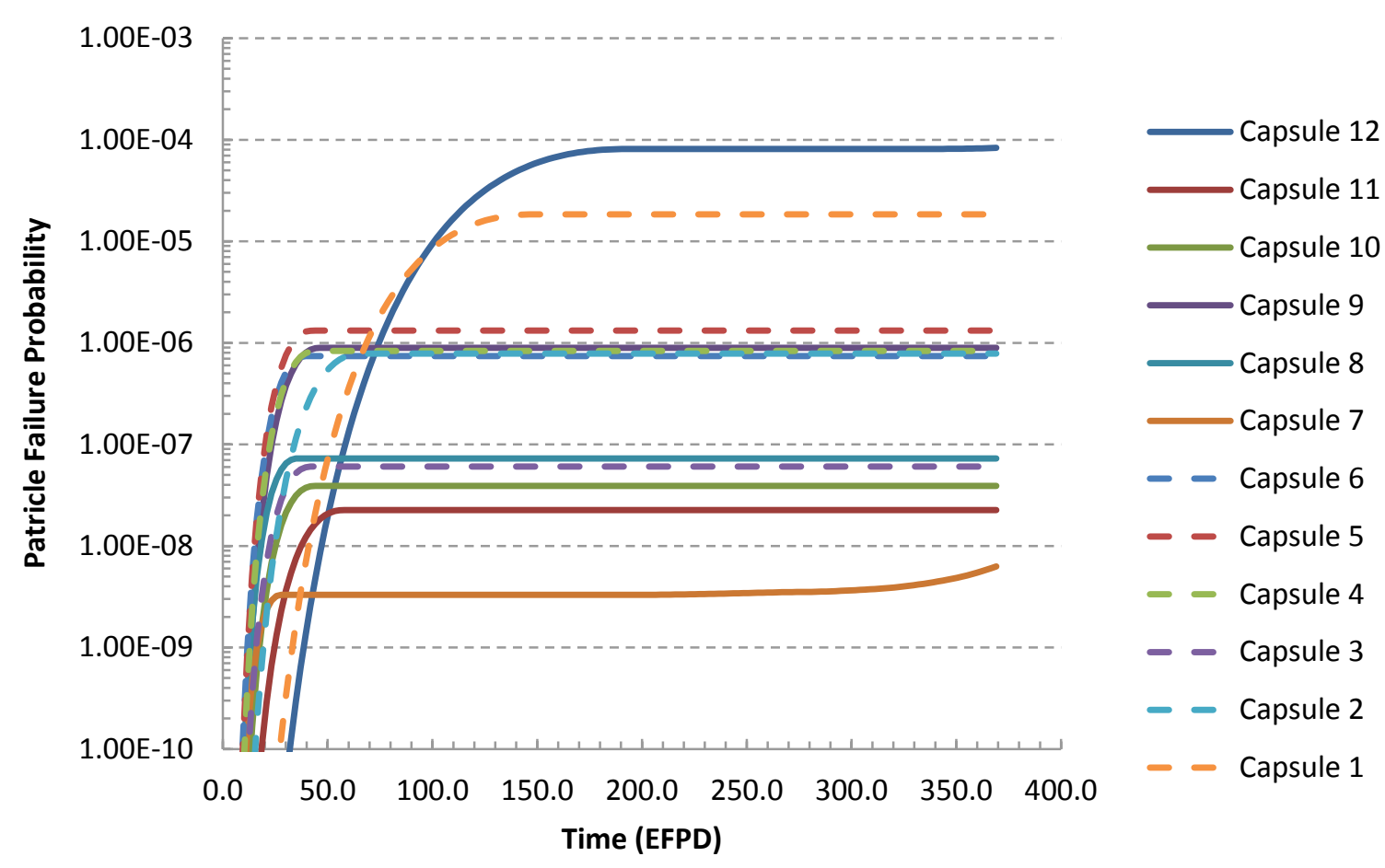

Figure 6. Fuel particle failure probabilities assuming volume-averaged capsule temperatures.

\subsection{Buffer-IPyC Gap}

Irradiation can lead to development of a gap between the buffer and IPyC layer. The gap can develop as a result of the combined effects of kernel swelling; shrinkage and creep in the buffer and IPyC layers; the effects of particle internal pressure, and the kernel/buffer contact pressure. However, differences in density between the buffer and the IPyC layer is a primary factor in the process. The buffer, which is much more porous than the dense IPyC layer, shrinks more during irradiation. The growth rate for the gap size slows as the buffer becomes denser during irradiation. The size of this gap is shown in Figure 7 for nominal particles, assuming the outer surfaces of those particles follow capsule-specific volume-averaged temperatures. Inspection of Figure 7 indicates that the gap width is closely correlated with fluence, which is correlated with the axial position of the capsules in the ATR core. Because ATR operates with a cosine-like profile, gap widths tend to be smallest in the outermost capsules (i.e., numbers 1 and 12 that are exposed to relatively low fluence levels) and largest in capsules at the core mid-plane (numbered 6 and 7 that are exposed to relatively high fluence levels).

The buffer-IPyC gap can be a significant fraction of the thermal resistance in a fuel particle. Consequently, if other conditions are equal, temperature differentials (i.e., from the kernel centerline to the outer surface of the $\mathrm{OPyC}$ ) are higher across particles with larger gaps. This trend is apparent in Figure 8, where temperature differentials are shown assuming the outer surfaces of particles follow volume-averaged temperatures. In Figure 8, temperature differentials are higher in Capsule 6 and 7 particles than in Capsules 1 and 12 particles, which would be expected given the capsule-to-capsule differences in the buffer-IPyC gaps (shown in Figures 7). 


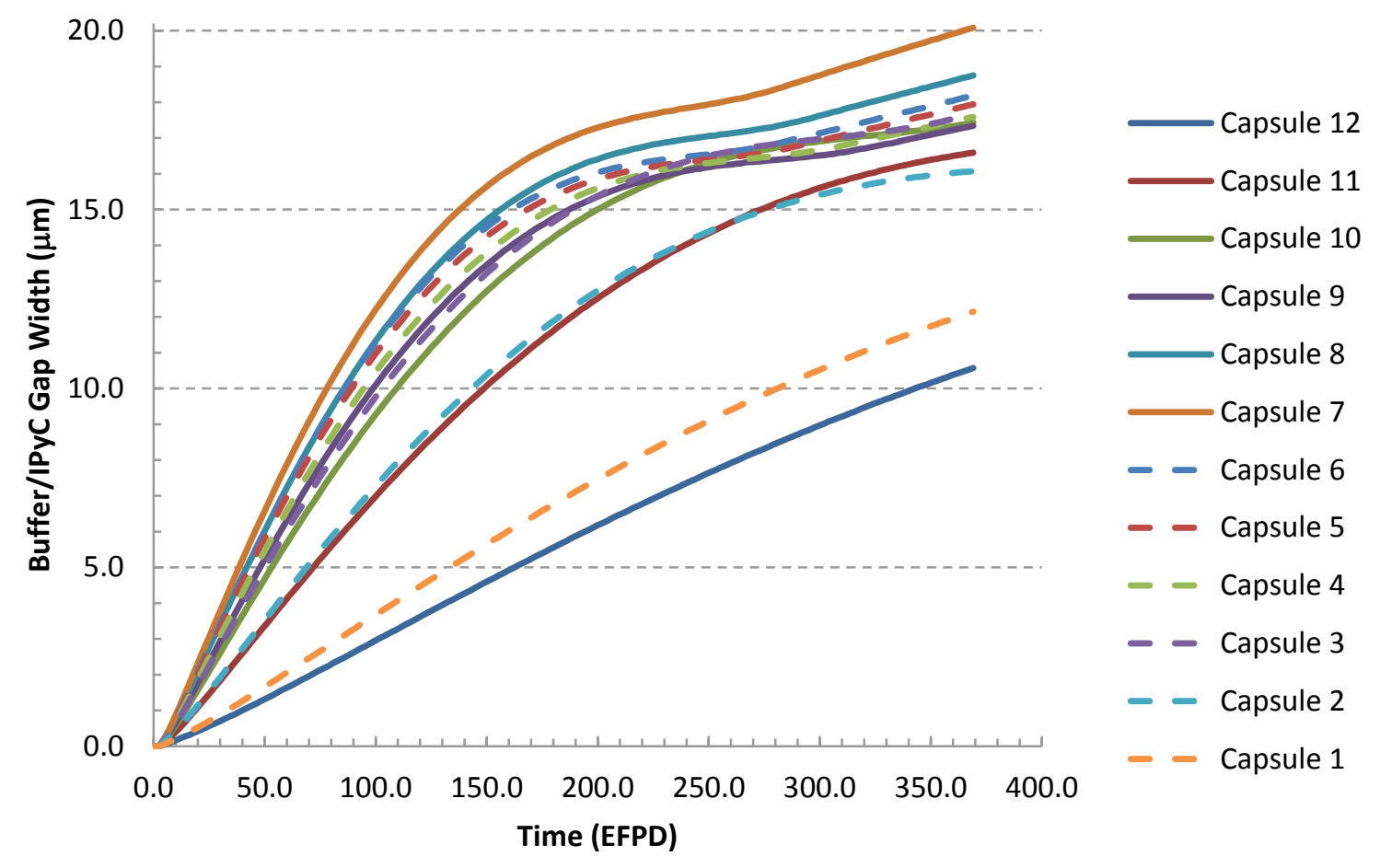

Figure 7. Buffer-IPyC gap width in nominal particles assuming volume-average capsule temperatures.

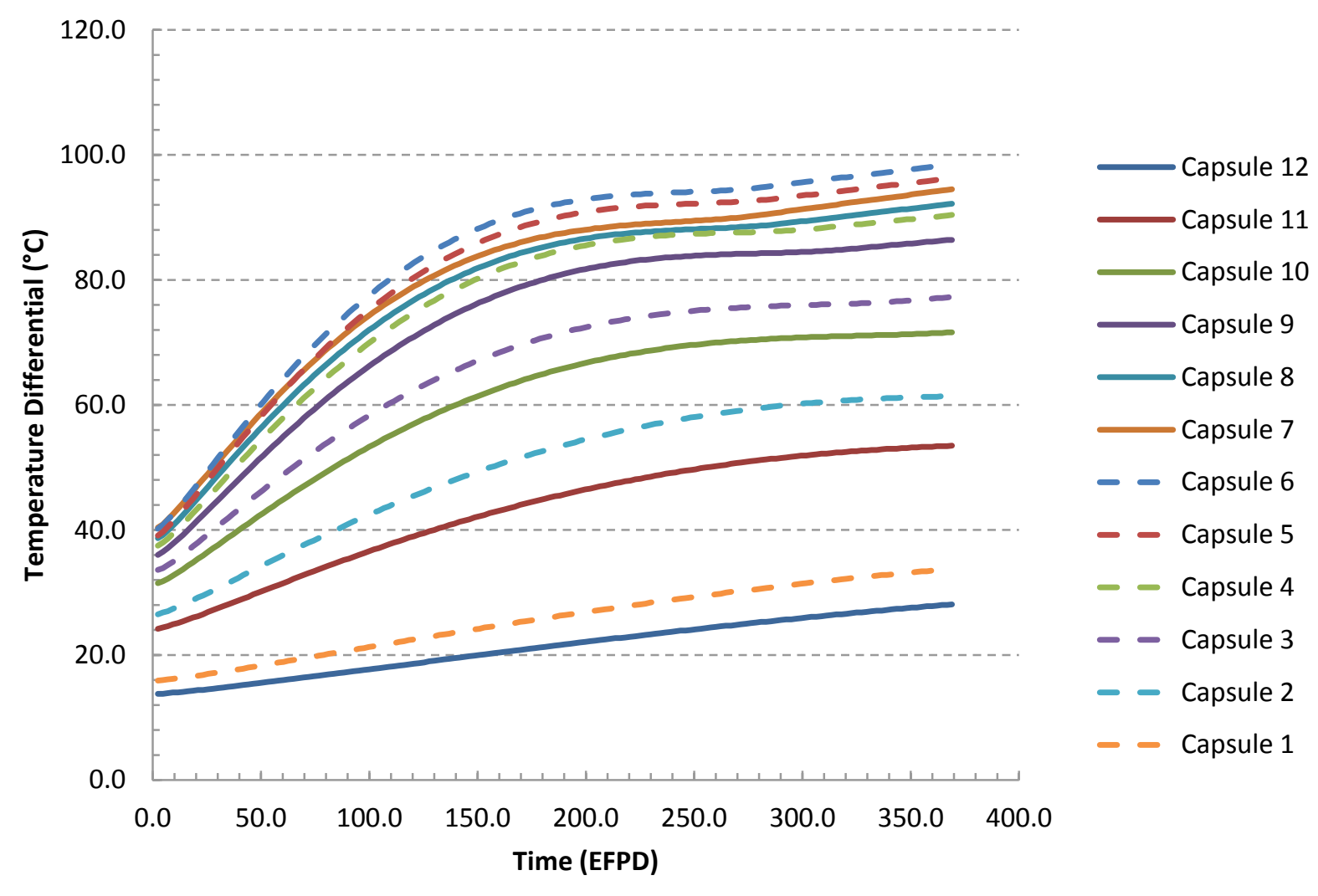

Figure 8. Particle temperature differentials (from the kernel centerline to the outer surface of the OPyC). 


\subsection{Release Fraction}

The release fraction from both the driver fuel and DTF fuel was also analyzed in a separate analysis using the specific volume-average daily temperatures of each of the 48 compacts of the AGR-3/4 test train. The daily temperatures (Collin 2015) were applied at the outer surface of the OPyC (driver fuel) and PyC seal coat (DTF). DTF particles were assumed to fail at the start of irradiation. The release from driver fuel and DTF particles includes uranium contamination in the OPyC layer $\left(3.5 \times 10^{-5}\right.$ and $5.3 \times 10^{-7}$, respectively) and $2 \%$ fission product recoil from the kernel. In the case of DTF particles, this contribution from recoil is readily released because the PyC seal coat is not retentive. A summary of the release fraction results can be found in Table 5, with the complete results presented in Appendix A. The results are based on the number of atoms released from 1,872 driver fuel particles and 20 DTF particles per compact. The results presented in this analysis can be used as the source term for further fission product diffusion analysis. Although the PARFUME predictions are based on failure of all the DTF particles at the start of irradiation, AGR-3/4 fission gas monitoring concluded that not all the DTF particles failed during the test. This potentially introduces discrepancies between the calculated and experimental inventories released from the DTF particles which will have to be taken into account in upcoming analysis of the experimental data and comparison to modeling results.

Table 5. Average fractional release by particles (1,872 driver fuel, 20 DTF)

\begin{tabular}{|l|l|l|l|l|l|l|}
\hline \multirow{2}{*}{ Capsule } & \multicolumn{4}{|l}{$\mathrm{Ag}$} & \multicolumn{2}{l}{ Cs } \\
\cline { 2 - 7 } & Driver & DTF & Driver & DTF & Driver & DTF \\
\hline 12 & $3.5 \mathrm{E}-05$ & $6.7 \mathrm{E}-01$ & $2.7 \mathrm{E}-05$ & $2.8 \mathrm{E}-01$ & $3.5 \mathrm{E}-05$ & $2.0 \mathrm{E}-02$ \\
\hline 11 & $2.6 \mathrm{E}-01$ & $1.0 \mathrm{E}+00$ & $3.7 \mathrm{E}-04$ & $1.0 \mathrm{E}+00$ & $1.2 \mathrm{E}-03$ & $2.4 \mathrm{E}-02$ \\
\hline 10 & $2.0 \mathrm{E}-01$ & $1.0 \mathrm{E}+00$ & $3.4 \mathrm{E}-04$ & $9.9 \mathrm{E}-01$ & $9.0 \mathrm{E}-04$ & $2.3 \mathrm{E}-02$ \\
\hline 9 & $1.2 \mathrm{E}-02$ & $9.9 \mathrm{E}-01$ & $3.5 \mathrm{E}-05$ & $9.1 \mathrm{E}-01$ & $3.7 \mathrm{E}-05$ & $2.0 \mathrm{E}-02$ \\
\hline 8 & $2.4 \mathrm{E}-01$ & $1.0 \mathrm{E}+00$ & $6.1 \mathrm{E}-04$ & $9.9 \mathrm{E}-01$ & $2.2 \mathrm{E}-03$ & $2.6 \mathrm{E}-02$ \\
\hline 7 & $5.0 \mathrm{E}-01$ & $1.0 \mathrm{E}+00$ & $7.3 \mathrm{E}-03$ & $1.0 \mathrm{E}+00$ & $2.4 \mathrm{E}-02$ & $4.9 \mathrm{E}-02$ \\
\hline 6 & $2.0 \mathrm{E}-02$ & $1.0 \mathrm{E}+00$ & $3.7 \mathrm{E}-05$ & $9.5 \mathrm{E}-01$ & $3.9 \mathrm{E}-05$ & $2.0 \mathrm{E}-02$ \\
\hline 5 & $6.5 \mathrm{E}-03$ & $9.8 \mathrm{E}-01$ & $3.4 \mathrm{E}-05$ & $8.4 \mathrm{E}-01$ & $3.6 \mathrm{E}-05$ & $2.0 \mathrm{E}-02$ \\
\hline 4 & $1.6 \mathrm{E}-02$ & $9.9 \mathrm{E}-01$ & $3.6 \mathrm{E}-05$ & $9.2 \mathrm{E}-01$ & $3.8 \mathrm{E}-05$ & $2.0 \mathrm{E}-02$ \\
\hline 3 & $1.2 \mathrm{E}-01$ & $1.0 \mathrm{E}+00$ & $1.6 \mathrm{E}-04$ & $9.7 \mathrm{E}-01$ & $3.4 \mathrm{E}-04$ & $2.1 \mathrm{E}-02$ \\
\hline 2 & $1.2 \mathrm{E}-02$ & $9.8 \mathrm{E}-01$ & $3.4 \mathrm{E}-05$ & $8.7 \mathrm{E}-01$ & $3.6 \mathrm{E}-05$ & $2.0 \mathrm{E}-02$ \\
\hline 1 & $6.4 \mathrm{E}-05$ & $8.7 \mathrm{E}-01$ & $3.2 \mathrm{E}-05$ & $5.0 \mathrm{E}-01$ & $3.5 \mathrm{E}-05$ & $2.0 \mathrm{E}-02$ \\
\hline
\end{tabular}




\section{Conclusion}

Fuel particle failure analysis was completed using PARFUME to analyze the failure probability of the AGR-3/4 irradiation test. The AGR-3/4 test consisted of irradiating twelve capsules in the NEFT position of the ATR for 369.1 EFPDs. Using as-run neutronic physics and thermal hydraulic data, the fuel particle failure probability, buffer-IPyC gap formation, and release from the driver fuel and DTF particles have been analyzed. The following summarizes the results derived from this work.

Failure probabilities are predicted to be low, resulting in zero driver fuel particle failures per capsule.

The irradiation conditions of the AGR-3/4 test result in zero driver fuel particle failures across all twelve capsules. The primary driver fuel particle failure mechanism that occurred was a result of localized stresses induced by the IPyC cracking. Assuming 1,872 driver fuel particles per compact, the failure probability as calculated by PARFUME estimates that AGR-3/4 will not result in any driver fuel particle failures. The capsules with the highest probability to experience driver fuel particle failure were Capsules 1 and 12. These capsules are irradiated at lower temperatures, resulting in a slower creep rate of the pyrocarbon layers, which causes an increase in localized stresses. The highest temperature capsule, number 7, had the lowest predicted fuel particle failure and, only at the end of the irradiation, experienced a slight increase in failure probability due to pressure vessel failure. The failure probability was still low enough that it did not result in any particle failures in Capsule 7.

Irradiation-induced shrinkage of the buffer and IPyC layer resulted in the formation of a buffer-IPyC gap.

As expected, shrinkage of the buffer and IPyC layer during irradiation resulted in formation of a buffer-IPyC gap. The two capsules at the two ends of the test train, Capsules 1 and 12, experienced the smallest buffer-IPyC gap formation due to their lower irradiation fluences. Capsule 7 experienced the largest buffer-IPyC gap formation of just over $20 \mu \mathrm{m}$.

The release fraction of fission products varies depending on temperature.

The release fraction of fission products $\mathrm{Ag}$, Cs, and $\mathrm{Sr}$ vary depending on capsule location and irradiation temperature. The maximum release fraction of Ag occurs in Capsule 7, reaching up to 50\% for the driver fuel and $100 \%$ for the DTF fuel. The release fraction of the other two fission products, Cs and $\mathrm{Sr}$ are much smaller and, in most cases, less than $1 \%$ for the driver fuel. The notable exception is again in Capsule 7, where the release fraction for $\mathrm{Cs}$ and $\mathrm{Ag}$ reach up to $0.73 \%$ and $2.4 \%$, respectively, for the

driver fuel. For the DTF fuel in Capsule 7, the release fraction for Cs and $\mathrm{Sr}$ are estimated to be $100 \%$ and $4.9 \%$, respectively. 


\section{References}

Abaqus/Standard, 2009, “Abaqus User's Manual,” Dassault Systemes Simulia Corp.

American Society of Mechanical Engineers, "NQA-1-2008/-1a-2009 Quality Assurance Requirements for Nuclear Facility Applications," March 2008 (Addenda August 2009).

Barnes, C.M., 2006a, “AGR-1 Fuel Product Specification and Characterization Guidance,” EDF-4380, Revision 8, Idaho National Laboratory, April 25, 2006.

Barnes, C.M., 2006b, “AGR-3 \& 4 Fuel Product Specification,” EDF-6638, Revision 1, Idaho National Laboratory, September 14, 2006.

BWXT, 2006, "Industrial Fuel Fabrication and Development Lot G73V-20-69303," Data Certification Package, BWX Technologies, June 6, 2006.

CEGA Corporation, 1993, "NP-MHTGR Material Models of Pyrocarbon and Pyrolytic Silicon Carbide," CEGA-002820, Revision 1, San Diego, CA, July 1993.

Collin, B.P., 2015, “AGR-3/4 Irradiation Test Final As-Run Report,” INL/EXT-15-35550, Revison 0, Idaho National Laboratory, June 2015.

Hunn, J.D., 2007, "Data Compilation for AGR-3/4 Driver Fuel Coated Particle Composite LEU03-09T," ORNL/TM-2007/019, Oak Ridge National Laboratory, March 2007.

Hunn, J.D., 2011, "Data Compilation for AGR-3/4 Designed-To-Fail (DTF) Fuel Particle Batch LEU0307DTF," ORNL/TM-2011/109, Oak Ridge National Laboratory, April 2011.

INL, 2015 "Technical Program Plan for the INL Advanced Reactor Technologies Technology Development Office/Advanced Gas Reactor Fuel Development and Qualification Program," PLN3636, Revision 4, Idaho National Laboratory, May 7, 2015.

Maki, J.T., 2011, “AGR-3/4 Irradiation Test Specification,” SPC-1345, Idaho National Laboratory, February 2, 2011.

Marshall, D.W., 2011, “AGR-3/4 DTF Fuel and Capsule Component Material Specifications,” SPC-1214, Revision 1, Idaho National Laboratory, June 21, 2011.

Miller, G. K., D. A. Petti, D. J. Varacalle Jr., and J. T. Maki, 2003, "Statistical Approach and Benchmarking for Modeling of Multi-Dimensional Behavior in TRISO-Coated Fuel Particles," Journal of Nuclear Materials, 317, p. 69-82.

Miller, G. K., D. A. Petti, and J. T. Maki, 2004, "Consideration of the Effects of Partial Debonding of the IPyC and Particle Asphericity on TRISO-Coated Fuel Behavior," Journal of Nuclear Materials, 334, p. 79-89.

Miller, G. K. and D.L. Knudson, 2007, “Advanced Gas Reactor-1 Pre-Test Prediction Analyses Using the PARFUME Code,” EDF-5741, Revision 1, Idaho National Laboratory, April 2007.

Miller, G.K., D. A. Petti, J. T. Maki, and D. L. Knudson, 2009, "PARFUME Theory and Model Basis Report," INL/EXT-08-14497, Idaho National Laboratory, September 2009.

Skerjanc, W.F., J.T. Maki, B.P. Collin, and D.A. Petti, 2016, "Evaluation of Design Parameters for TRISO-Coated Fuel Particles to Establish Manufacturing Critical Limits Using PARFUME,” Journal of Nuclear Materials, 469, p.99-105, 2016. 
Appendix A

\section{Fuel Particle Release Fraction}


Table A1. Summary of inventory (number of atoms) released by the particles (1,872 driver fuel, 20 DTF)

\begin{tabular}{|c|c|c|c|c|c|c|c|c|c|}
\hline \multirow{2}{*}{ Caps } & \multirow{2}{*}{ Level } & \multirow{2}{*}{$\begin{array}{c}\text { Burnup } \\
\text { (\%FIMA) }\end{array}$} & \multirow{2}{*}{$\begin{array}{c}\text { Fluence } \\
\left(\times 10^{25} \mathrm{n} / \mathrm{m}^{2}\right)\end{array}$} & \multicolumn{2}{|c|}{$\mathrm{Ag}$} & \multicolumn{2}{|c|}{ Cs } & \multicolumn{2}{|c|}{$\mathrm{Sr}$} \\
\hline & & & & Driver & DTF & Driver & DTF & Driver & DTF \\
\hline 12 & 4 & 4.85 & 1.19 & $2.5 \mathrm{E}+12$ & $4.6 \mathrm{E}+14$ & $2.2 \mathrm{E}+14$ & $2.2 \mathrm{E}+16$ & $2.0 \mathrm{E}+14$ & $1.3 \mathrm{E}+15$ \\
\hline 12 & 3 & 5.17 & 1.41 & $2.8 \mathrm{E}+12$ & $6.1 \mathrm{E}+14$ & $2.6 \mathrm{E}+14$ & $3.1 \mathrm{E}+16$ & $2.2 E+14$ & $1.3 \mathrm{E}+15$ \\
\hline 12 & 2 & 5.52 & 1.60 & $3.0 \mathrm{E}+12$ & $7.0 \mathrm{E}+14$ & $2.8 \mathrm{E}+14$ & $3.6 \mathrm{E}+16$ & $2.3 E+14$ & $1.4 \mathrm{E}+15$ \\
\hline 12 & 1 & 5.87 & 1.80 & $3.3 \mathrm{E}+12$ & $6.8 \mathrm{E}+14$ & $2.8 \mathrm{E}+14$ & $3.1 \mathrm{E}+16$ & $2.4 \mathrm{E}+14$ & $1.5 \mathrm{E}+15$ \\
\hline 11 & 4 & 8.42 & 2.61 & $3.1 \mathrm{E}+16$ & $1.8 \mathrm{E}+15$ & $2.0 \mathrm{E}+15$ & $1.6 \mathrm{E}+17$ & $3.1 \mathrm{E}+15$ & $2.2 \mathrm{E}+15$ \\
\hline 11 & 3 & 8.89 & 2.80 & $5.5 E+16$ & $1.9 \mathrm{E}+15$ & $8.2 \mathrm{E}+15$ & 1.7E+17 & $1.6 \mathrm{E}+16$ & 2.7E+15 \\
\hline 11 & 2 & 9.30 & 2.96 & $6.2 \mathrm{E}+16$ & $2.1 \mathrm{E}+15$ & $1.1 \mathrm{E}+16$ & $1.8 \mathrm{E}+17$ & $2.2 \mathrm{E}+16$ & $2.9 \mathrm{E}+15$ \\
\hline 11 & 1 & 9.64 & 3.11 & $4.0 \mathrm{E}+16$ & $2.2 \mathrm{E}+15$ & $3.3 \mathrm{E}+15$ & $1.9 \mathrm{E}+17$ & $5.0 \mathrm{E}+15$ & $2.5 \mathrm{E}+15$ \\
\hline 10 & 4 & 11.43 & 3.75 & $3.8 \mathrm{E}+16$ & $2.8 \mathrm{E}+15$ & $2.8 \mathrm{E}+15$ & $2.2 \mathrm{E}+17$ & $3.7 \mathrm{E}+15$ & $2.8 \mathrm{E}+15$ \\
\hline 10 & 3 & 11.75 & 3.89 & $6.4 \mathrm{E}+16$ & $3.0 \mathrm{E}+15$ & $1.0 \mathrm{E}+16$ & $2.3 \mathrm{E}+17$ & $1.7 \mathrm{E}+16$ & $3.3 \mathrm{E}+15$ \\
\hline 10 & 2 & 11.96 & 4.01 & $6.8 \mathrm{E}+16$ & $3.0 \mathrm{E}+15$ & $1.2 \mathrm{E}+16$ & $2.3 \mathrm{E}+17$ & $2.0 \mathrm{E}+16$ & $3.4 \mathrm{E}+15$ \\
\hline 10 & 1 & 12.08 & 4.12 & $4.4 \mathrm{E}+16$ & $3.1 \mathrm{E}+15$ & $4.0 \mathrm{E}+15$ & $2.3 \mathrm{E}+17$ & $4.9 \mathrm{E}+15$ & $3.0 \mathrm{E}+15$ \\
\hline 9 & 4 & 13.40 & 4.53 & $2.1 \mathrm{E}+15$ & $3.6 \mathrm{E}+15$ & $8.3 E+14$ & $2.3 \mathrm{E}+17$ & $4.9 E+14$ & $3.0 \mathrm{E}+15$ \\
\hline 9 & 3 & 13.63 & 4.63 & $7.0 \mathrm{E}+15$ & 3.7E+15 & $8.8 \mathrm{E}+14$ & $2.5 \mathrm{E}+17$ & $5.4 \mathrm{E}+14$ & $3.1 \mathrm{E}+15$ \\
\hline 9 & 2 & 13.78 & 4.70 & $7.5 E+15$ & $3.8 \mathrm{E}+15$ & $8.9 E+14$ & $2.6 \mathrm{E}+17$ & $5.5 \mathrm{E}+14$ & $3.1 \mathrm{E}+15$ \\
\hline 9 & 1 & 13.87 & 4.76 & $2.0 \mathrm{E}+15$ & $3.8 \mathrm{E}+15$ & $8.6 \mathrm{E}+14$ & $2.4 \mathrm{E}+17$ & $5.1 \mathrm{E}+14$ & $3.1 \mathrm{E}+15$ \\
\hline 8 & 4 & 14.43 & 5.02 & $7.4 \mathrm{E}+16$ & $4.0 \mathrm{E}+15$ & 7.7E+15 & $2.8 \mathrm{E}+17$ & $1.5 \mathrm{E}+16$ & $3.8 \mathrm{E}+15$ \\
\hline 8 & 3 & 14.54 & 5.07 & $1.1 \mathrm{E}+17$ & $4.1 \mathrm{E}+15$ & $2.4 \mathrm{E}+16$ & $2.8 \mathrm{E}+17$ & $5.1 \mathrm{E}+16$ & $4.6 \mathrm{E}+15$ \\
\hline 8 & 2 & 14.58 & 5.11 & $1.1 \mathrm{E}+17$ & $4.1 \mathrm{E}+15$ & $2.5 \mathrm{E}+16$ & $2.9 \mathrm{E}+17$ & $5.2 \mathrm{E}+16$ & 4.7E+15 \\
\hline 8 & 1 & 14.51 & 5.13 & $7.1 \mathrm{E}+16$ & 4.1E+15 & $7.4 \mathrm{E}+15$ & $2.8 \mathrm{E}+17$ & $1.4 \mathrm{E}+16$ & 3.7E+15 \\
\hline 7 & 4 & 14.90 & 5.24 & $1.8 \mathrm{E}+17$ & $4.2 \mathrm{E}+15$ & $1.4 \mathrm{E}+17$ & $2.9 \mathrm{E}+17$ & $2.3 \mathrm{E}+17$ & $6.6 \mathrm{E}+15$ \\
\hline 7 & 3 & 15.00 & 5.27 & $2.2 \mathrm{E}+17$ & 4. $3 E+15$ & $2.6 \mathrm{E}+17$ & $2.9 \mathrm{E}+17$ & $5.3 \mathrm{E}+17$ & $1.0 \mathrm{E}+16$ \\
\hline 7 & 2 & 15.02 & 5.29 & $2.2 \mathrm{E}+17$ & $4.3 E+15$ & $2.6 \mathrm{E}+17$ & $2.9 \mathrm{E}+17$ & $5.2 \mathrm{E}+17$ & $1.0 \mathrm{E}+16$ \\
\hline 7 & 1 & 14.92 & 5.28 & 1.7E+17 & $4.2 E+15$ & $1.2 \mathrm{E}+17$ & $2.9 \mathrm{E}+17$ & $1.9 \mathrm{E}+17$ & $6.1 \mathrm{E}+15$ \\
\hline 6 & 4 & 15.26 & 5.31 & $4.9 \mathrm{E}+15$ & $4.4 \mathrm{E}+15$ & $9.6 \mathrm{E}+14$ & $2.8 \mathrm{E}+17$ & $5.6 \mathrm{E}+14$ & $3.4 \mathrm{E}+15$ \\
\hline 6 & 3 & 15.27 & 5.32 & $1.3 \mathrm{E}+16$ & 4. $4 \mathrm{E}+15$ & $1.1 \mathrm{E}+15$ & $2.9 \mathrm{E}+17$ & $6.5 \mathrm{E}+14$ & $3.4 \mathrm{E}+15$ \\
\hline 6 & 2 & 15.23 & 5.32 & $1.2 \mathrm{E}+16$ & 4.4E+15 & $1.1 \mathrm{E}+15$ & $2.9 \mathrm{E}+17$ & $6.4 \mathrm{E}+14$ & $3.4 \mathrm{E}+15$ \\
\hline 6 & 1 & 15.21 & 5.30 & $2.9 \mathrm{E}+15$ & $4.3 \mathrm{E}+15$ & $9.5 \mathrm{E}+14$ & 2.7E+17 & $5.5 \mathrm{E}+14$ & $3.4 \mathrm{E}+15$ \\
\hline 5 & 4 & 14.98 & 5.23 & $8.6 E+14$ & $4.2 E+15$ & $9.1 \mathrm{E}+14$ & $2.4 \mathrm{E}+17$ & $5.4 \mathrm{E}+14$ & $3.3 \mathrm{E}+15$ \\
\hline 5 & 3 & 14.92 & 5.22 & 4.7E+15 & 4. $2 \mathrm{E}+15$ & $9.4 \mathrm{E}+14$ & $2.6 \mathrm{E}+17$ & $5.7 \mathrm{E}+14$ & $3.3 \mathrm{E}+15$ \\
\hline 5 & 2 & 14.86 & 5.18 & $4.3 \mathrm{E}+15$ & $4.2 \mathrm{E}+15$ & $9.3 \mathrm{E}+14$ & $2.6 \mathrm{E}+17$ & $5.7 \mathrm{E}+14$ & $3.3 \mathrm{E}+15$ \\
\hline 5 & 1 & 14.74 & 5.14 & $4.0 \mathrm{E}+14$ & $4.0 \mathrm{E}+15$ & $8.9 E+14$ & $2.2 \mathrm{E}+17$ & $5.3 \mathrm{E}+14$ & $3.3 \mathrm{E}+15$ \\
\hline 4 & 4 & 14.41 & 4.92 & $3.5 \mathrm{E}+15$ & $4.0 \mathrm{E}+15$ & $9.0 \mathrm{E}+14$ & $2.6 \mathrm{E}+17$ & $5.3 \mathrm{E}+14$ & $3.2 \mathrm{E}+15$ \\
\hline 4 & 3 & 14.29 & 4.89 & $9.9 \mathrm{E}+15$ & $4.0 \mathrm{E}+15$ & $9.7 \mathrm{E}+14$ & 2.7E+17 & $6.0 \mathrm{E}+14$ & $3.2 E+15$ \\
\hline 4 & 2 & 14.16 & 4.83 & $8.5 E+15$ & $3.9 \mathrm{E}+15$ & $9.3 \mathrm{E}+14$ & 2.7E+17 & $5.7 \mathrm{E}+14$ & $3.2 E+15$ \\
\hline 4 & 1 & 13.98 & 4.74 & $1.3 \mathrm{E}+15$ & 4.0E+15 & $8.6 \mathrm{E}+14$ & $2.4 \mathrm{E}+17$ & $5.1 \mathrm{E}+14$ & 3. $2 \mathrm{E}+15$ \\
\hline 3 & 4 & 12.93 & 4.38 & $3.2 \mathrm{E}+16$ & $3.4 \mathrm{E}+15$ & $2.5 \mathrm{E}+15$ & $2.5 \mathrm{E}+17$ & $2.6 \mathrm{E}+15$ & $3.0 \mathrm{E}+15$ \\
\hline 3 & 3 & 12.73 & 4.28 & $5.0 \mathrm{E}+16$ & $3.3 \mathrm{E}+15$ & $6.4 \mathrm{E}+15$ & $2.5 \mathrm{E}+17$ & $5.9 \mathrm{E}+15$ & $3.1 \mathrm{E}+15$ \\
\hline 3 & 2 & 12.49 & 4.17 & $4.3 E+16$ & $3.2 E+15$ & 4.7E+15 & $2.4 \mathrm{E}+17$ & $5.9 \mathrm{E}+15$ & $3.1 \mathrm{E}+15$ \\
\hline 3 & 1 & 12.16 & 4.04 & $1.9 \mathrm{E}+16$ & $3.1 \mathrm{E}+15$ & $1.1 \mathrm{E}+15$ & $2.3 \mathrm{E}+17$ & $9.7 \mathrm{E}+14$ & $2.8 \mathrm{E}+15$ \\
\hline 2 & 4 & 10.65 & 3.44 & $2.6 \mathrm{E}+15$ & $2.5 \mathrm{E}+15$ & $6.6 \mathrm{E}+14$ & $1.9 \mathrm{E}+17$ & $4.1 \mathrm{E}+14$ & $2.5 \mathrm{E}+15$ \\
\hline 2 & 3 & 10.29 & 3.30 & $4.4 \mathrm{E}+15$ & $2.4 \mathrm{E}+15$ & $6.5 \mathrm{E}+14$ & $1.9 \mathrm{E}+17$ & $4.1 \mathrm{E}+14$ & $2.4 \mathrm{E}+15$ \\
\hline 2 & 2 & 9.90 & 3.14 & $2.9 \mathrm{E}+15$ & $2.3 \mathrm{E}+15$ & $6.2 \mathrm{E}+14$ & $1.8 \mathrm{E}+17$ & $3.9 \mathrm{E}+14$ & 2.3E+15 \\
\hline 2 & 1 & 9.43 & 2.95 & $4.9 \mathrm{E}+14$ & $2.1 \mathrm{E}+15$ & $5.8 \mathrm{E}+14$ & $1.4 \mathrm{E}+17$ & $3.6 \mathrm{E}+14$ & 2.2E+15 \\
\hline 1 & 4 & 6.85 & 2.10 & $4.8 \mathrm{E}+12$ & $1.2 \mathrm{E}+15$ & $3.9 E+14$ & $6.7 \mathrm{E}+16$ & $2.8 \mathrm{E}+14$ & 1.7E+15 \\
\hline 1 & 3 & 6.37 & 1.87 & $1.3 \mathrm{E}+13$ & $1.1 \mathrm{E}+15$ & $3.8 \mathrm{E}+14$ & $7.6 \mathrm{E}+16$ & $2.6 \mathrm{E}+14$ & $1.6 \mathrm{E}+15$ \\
\hline 1 & 2 & 5.91 & 1.66 & $5.3 \mathrm{E}+12$ & $9.6 \mathrm{E}+14$ & $3.4 \mathrm{E}+14$ & $6.3 \mathrm{E}+16$ & $2.4 \mathrm{E}+14$ & $1.5 \mathrm{E}+15$ \\
\hline 1 & 1 & 5.43 & 1.42 & $3.0 \mathrm{E}+12$ & $7.0 \mathrm{E}+14$ & $2.9 \mathrm{E}+14$ & $3.6 \mathrm{E}+16$ & $2.3 \mathrm{E}+14$ & 1.4E+15 \\
\hline
\end{tabular}


Table A2. Summary of fractional release by the particles (1,872 driver fuel, 20 DTF)

\begin{tabular}{|c|c|c|c|c|c|c|c|c|c|}
\hline \multirow{2}{*}{ Caps } & \multirow{2}{*}{ Level } & \multirow{2}{*}{$\begin{array}{l}\text { Burnup } \\
\text { (\%FIMA) }\end{array}$} & \multirow{2}{*}{$\begin{array}{c}\text { Fluence } \\
\left(\times 10^{25} \mathrm{n} / \mathrm{m}^{2}\right)\end{array}$} & \multicolumn{2}{|c|}{$\mathrm{Ag}$} & \multicolumn{2}{|c|}{ Cs } & \multicolumn{2}{|c|}{$\mathrm{Sr}$} \\
\hline & & & & Driver & DTF & Driver & DTF & Driver & DTF \\
\hline 12 & 4 & 4.85 & 1.19 & $3.5 \mathrm{E}-05$ & $5.9 \mathrm{E}-01$ & $2.5 \mathrm{E}-05$ & $2.3 \mathrm{E}-01$ & $3.5 \mathrm{E}-05$ & 2.0E-02 \\
\hline 12 & 3 & 5.17 & 1.41 & 3.5E-05 & 7.1E-01 & $2.8 \mathrm{E}-05$ & 3.1E-01 & $3.5 \mathrm{E}-05$ & 2.0E-02 \\
\hline 12 & 2 & 5.52 & 1.60 & $3.5 \mathrm{E}-05$ & 7.4E-01 & $2.9 \mathrm{E}-05$ & 3.3E-01 & $3.5 \mathrm{E}-05$ & 2.0E-02 \\
\hline 12 & 1 & 5.87 & 1.80 & 3.5E-05 & $6.5 \mathrm{E}-01$ & 2.7E-05 & 2.7E-01 & $3.5 \mathrm{E}-05$ & 2.0E-02 \\
\hline 11 & 4 & 8.42 & 2.61 & $1.9 \mathrm{E}-01$ & $1.0 \mathrm{E}+00$ & $1.3 \mathrm{E}-04$ & $9.9 \mathrm{E}-01$ & $3.4 \mathrm{E}-04$ & $2.2 \mathrm{E}-02$ \\
\hline 11 & 3 & 8.89 & 2.80 & 3.1E-01 & $1.0 \mathrm{E}+00$ & 5.1E-04 & $1.0 \mathrm{E}+00$ & 1.7E-03 & 2.5E-02 \\
\hline 11 & 2 & 9.30 & 2.96 & 3.2E-01 & $1.0 \mathrm{E}+00$ & $6.5 \mathrm{E}-04$ & $1.0 \mathrm{E}+00$ & $2.1 \mathrm{E}-03$ & 2.6E-02 \\
\hline 11 & 1 & 9.64 & 3.11 & 2.0E-01 & $1.0 \mathrm{E}+00$ & $1.9 \mathrm{E}-04$ & $9.9 \mathrm{E}-01$ & 4.7E-04 & 2.2E-02 \\
\hline 10 & 4 & 11.43 & 3.75 & $1.5 \mathrm{E}-01$ & $1.0 \mathrm{E}+00$ & $1.4 \mathrm{E}-04$ & $9.8 \mathrm{E}-01$ & $3.0 \mathrm{E}-04$ & $2.1 \mathrm{E}-02$ \\
\hline 10 & 3 & 11.75 & 3.89 & 2.4E-01 & $1.0 \mathrm{E}+00$ & 4.9E-04 & $9.9 \mathrm{E}-01$ & $1.4 \mathrm{E}-03$ & 2.4E-02 \\
\hline 10 & 2 & 11.96 & 4.01 & $2.5 \mathrm{E}-01$ & $1.0 \mathrm{E}+00$ & 5.7E-04 & $9.9 \mathrm{E}-01$ & 1.6E-03 & 2.4E-02 \\
\hline 10 & 1 & 12.08 & 4.12 & $1.5 \mathrm{E}-01$ & $1.0 \mathrm{E}+00$ & $1.8 \mathrm{E}-04$ & $9.8 \mathrm{E}-01$ & $3.8 \mathrm{E}-04$ & 2.1E-02 \\
\hline 9 & 4 & 13.40 & 4.53 & $6.3 \mathrm{E}-03$ & $9.9 \mathrm{E}-01$ & $3.4 \mathrm{E}-05$ & $8.8 \mathrm{E}-01$ & $3.5 \mathrm{E}-05$ & 2.0E-02 \\
\hline 9 & 3 & 13.63 & 4.63 & $2.1 \mathrm{E}-02$ & $1.0 \mathrm{E}+00$ & 3.6E-05 & $9.4 \mathrm{E}-01$ & $3.8 \mathrm{E}-05$ & 2.0E-02 \\
\hline 9 & 2 & 13.78 & 4.70 & $2.2 \mathrm{E}-02$ & $1.0 \mathrm{E}+00$ & $3.6 \mathrm{E}-05$ & $9.4 \mathrm{E}-01$ & $3.8 \mathrm{E}-05$ & 2.0E-02 \\
\hline 9 & 1 & 13.87 & 4.76 & 3.5E-05 & 9.9E-01 & $3.4 \mathrm{E}-05$ & 8.7E-01 & 3.5E-05 & 2.0E-02 \\
\hline 8 & 4 & 14.43 & 5.02 & $2.0 \mathrm{E}-01$ & $1.0 \mathrm{E}+00$ & $2.9 \mathrm{E}-04$ & $9.9 \mathrm{E}-01$ & $1.0 \mathrm{E}-03$ & $2.3 \mathrm{E}-02$ \\
\hline 8 & 3 & 14.54 & 5.07 & $2.9 \mathrm{E}-01$ & $1.0 \mathrm{E}+00$ & $9.2 \mathrm{E}-04$ & $9.9 \mathrm{E}-01$ & $3.4 \mathrm{E}-03$ & 2.9E-02 \\
\hline 8 & 2 & 14.58 & 5.11 & $2.9 \mathrm{E}-01$ & $1.0 \mathrm{E}+00$ & $9.4 \mathrm{E}-04$ & $9.9 \mathrm{E}-01$ & $3.5 \mathrm{E}-03$ & 2.9E-02 \\
\hline 8 & 1 & 14.51 & 5.13 & $1.9 \mathrm{E}-01$ & $1.0 \mathrm{E}+00$ & $2.8 \mathrm{E}-04$ & $9.9 \mathrm{E}-01$ & $9.3 \mathrm{E}-04$ & 2.3E-02 \\
\hline 7 & 4 & 14.90 & 5.24 & $4.6 \mathrm{E}-01$ & $1.0 \mathrm{E}+00$ & $5.1 \mathrm{E}-03$ & $1.0 \mathrm{E}+00$ & $1.5 \mathrm{E}-02$ & 3.9E-02 \\
\hline 7 & 3 & 15.00 & 5.27 & 5.6E-01 & $1.0 \mathrm{E}+00$ & 9.7E-03 & $1.0 \mathrm{E}+00$ & $3.4 \mathrm{E}-02$ & $6.0 \mathrm{E}-02$ \\
\hline 7 & 2 & 15.02 & 5.29 & $5.6 \mathrm{E}-01$ & $1.0 \mathrm{E}+00$ & $9.6 \mathrm{E}-03$ & $1.0 \mathrm{E}+00$ & $3.4 \mathrm{E}-02$ & $6.0 \mathrm{E}-02$ \\
\hline 7 & 1 & 14.92 & 5.28 & 4.4E-01 & $1.0 \mathrm{E}+00$ & 4.6E-03 & $1.0 \mathrm{E}+00$ & 1.3E-02 & 3.7E-02 \\
\hline 6 & 4 & 15.26 & 5.31 & $1.2 \mathrm{E}-02$ & $1.0 \mathrm{E}+00$ & $3.5 \mathrm{E}-05$ & $9.4 \mathrm{E}-01$ & $3.6 \mathrm{E}-05$ & 2.0E-02 \\
\hline 6 & 3 & 15.27 & 5.32 & 3.1E-02 & $1.0 \mathrm{E}+00$ & 4.0E-05 & 9.7E-01 & 4.2E-05 & 2.0E-02 \\
\hline 6 & 2 & 15.23 & 5.32 & 3.0E-02 & $1.0 \mathrm{E}+00$ & $3.9 \mathrm{E}-05$ & 9.7E-01 & 4.1E-05 & 2.0E-02 \\
\hline 6 & 1 & 15.21 & 5.30 & 7.1E-03 & $9.9 \mathrm{E}-01$ & $3.5 \mathrm{E}-05$ & $9.0 \mathrm{E}-01$ & $3.5 \mathrm{E}-05$ & 2.0E-02 \\
\hline 5 & 4 & 14.98 & 5.23 & $2.2 \mathrm{E}-03$ & 9.7E-01 & $3.4 \mathrm{E}-05$ & $8.1 \mathrm{E}-01$ & $3.5 \mathrm{E}-05$ & $2.0 \mathrm{E}-02$ \\
\hline 5 & 3 & 14.92 & 5.22 & $1.2 \mathrm{E}-02$ & 9.9E-01 & $3.5 \mathrm{E}-05$ & $9.0 \mathrm{E}-01$ & $3.8 \mathrm{E}-05$ & 2.0E-02 \\
\hline 5 & 2 & 14.86 & 5.18 & 1.1E-02 & $9.8 \mathrm{E}-01$ & 3.5E-05 & 9.0E-01 & 3.7E-05 & 2.0E-02 \\
\hline 5 & 1 & 14.74 & 5.14 & $1.1 \mathrm{E}-03$ & 9.6E-01 & 3.3E-05 & 7.6E-01 & $3.5 \mathrm{E}-05$ & 2.0E-02 \\
\hline 4 & 4 & 14.41 & 4.92 & $9.5 \mathrm{E}-03$ & 9.9E-01 & $3.5 \mathrm{E}-05$ & $9.1 \mathrm{E}-01$ & $3.6 \mathrm{E}-05$ & 2.0E-02 \\
\hline 4 & 3 & 14.29 & 4.89 & 2.7E-02 & $1.0 \mathrm{E}+00$ & 3.7E-05 & $9.6 \mathrm{E}-01$ & 4.1E-05 & 2.0E-02 \\
\hline 4 & 2 & 14.16 & 4.83 & $2.3 \mathrm{E}-02$ & $1.0 \mathrm{E}+00$ & $3.6 \mathrm{E}-05$ & $9.6 \mathrm{E}-01$ & $3.9 \mathrm{E}-05$ & 2.0E-02 \\
\hline 4 & 1 & 13.98 & 4.74 & 3.7E-03 & 9.9E-01 & $3.4 \mathrm{E}-05$ & 8.4E-01 & $3.5 \mathrm{E}-05$ & 2.0E-02 \\
\hline 3 & 4 & 12.93 & 4.38 & $1.0 \mathrm{E}-01$ & $1.0 \mathrm{E}+00$ & $1.1 \mathrm{E}-04$ & 9.7E-01 & $1.9 \mathrm{E}-04$ & $2.1 \mathrm{E}-02$ \\
\hline 3 & 3 & 12.73 & 4.28 & 1.6E-01 & $1.0 \mathrm{E}+00$ & $2.8 \mathrm{E}-04$ & $9.8 \mathrm{E}-01$ & $6.3 \mathrm{E}-04$ & 2.2E-02 \\
\hline 3 & 2 & 12.49 & 4.17 & $1.5 \mathrm{E}-01$ & $1.0 \mathrm{E}+00$ & $2.1 \mathrm{E}-04$ & $9.8 \mathrm{E}-01$ & $4.5 \mathrm{E}-04$ & 2.2E-02 \\
\hline 3 & 1 & 12.16 & 4.04 & 6.5E-02 & 9.9E-01 & 5.1E-05 & $9.6 \mathrm{E}-01$ & 7.5E-05 & 2.0E-02 \\
\hline 2 & 4 & 10.65 & 3.44 & $1.1 \mathrm{E}-02$ & $9.9 \mathrm{E}-01$ & $3.4 \mathrm{E}-05$ & $8.8 \mathrm{E}-01$ & $3.6 \mathrm{E}-05$ & 2.0E-02 \\
\hline 2 & 3 & 10.29 & 3.30 & $2.0 \mathrm{E}-02$ & 9.9E-01 & 3.5E-05 & $9.2 \mathrm{E}-01$ & 3.7E-05 & 2.0E-02 \\
\hline 2 & 2 & 9.90 & 3.14 & $1.4 \mathrm{E}-02$ & 9.9E-01 & 3.5E-05 & $9.0 \mathrm{E}-01$ & 3.6E-05 & 2.0E-02 \\
\hline 2 & 1 & 9.43 & 2.95 & $2.5 \mathrm{E}-03$ & 9.7E-01 & $3.4 \mathrm{E}-05$ & $7.8 \mathrm{E}-01$ & $3.5 \mathrm{E}-05$ & 2.0E-02 \\
\hline 1 & 4 & 6.85 & 2.10 & $4.0 \mathrm{E}-05$ & $8.8 \mathrm{E}-01$ & $3.2 \mathrm{E}-05$ & $5.0 \mathrm{E}-01$ & $3.5 \mathrm{E}-05$ & 2.0E-02 \\
\hline 1 & 3 & 6.37 & 1.87 & $1.2 \mathrm{E}-04$ & $9.4 \mathrm{E}-01$ & 3.3E-05 & 6.1E-01 & $3.5 \mathrm{E}-05$ & 2.0E-02 \\
\hline 1 & 2 & 5.91 & 1.66 & 5.5E-05 & $9.1 \mathrm{E}-01$ & $3.2 \mathrm{E}-05$ & $5.4 \mathrm{E}-01$ & $3.5 \mathrm{E}-05$ & 2.0E-02 \\
\hline 1 & 1 & 5.43 & 1.42 & $3.5 \mathrm{E}-05$ & 7.6E-01 & 3.0E-05 & $3.4 \mathrm{E}-01$ & $3.5 \mathrm{E}-05$ & 2.0E-02 \\
\hline
\end{tabular}

